\title{
Benin: 2008 Article IV Consultation and Fourth Review Under the Three-Year Arrangement Under the Poverty Reduction and Growth Facility and Request for Augmentation of Access-Staff Report; Public Information Notice and Press Release on the Executive Board Discussion; and Statement by the Executive Director for Benin
}

Under Article IV of the IMF's Articles of Agreement, the IMF holds bilateral discussions with members, usually every year. In the context of a combined discussion of the 2008 Article IV consultation with Benin and fourth review under the three-year arrangement under the Poverty Reduction and Growth Facility and request for augmentation of access, the following documents have been released and are included in this package:

- $\quad$ The staff report for the combined 2008 Article IV Consultation and Fourth Review Under the Three-Year Arrangement Under the Poverty Reduction and Growth Facility and Request for Augmentation of Access, prepared by a staff team of the IMF, following discussions that ended on March 17, 2008, with the officials of Benin on economic developments and policies. Based on information available at the time of these discussions, the staff report was completed on May 30, 2008. The views expressed in the staff report are those of the staff team and do not necessarily reflect the views of the Executive Board of the IMF.

- A Press Release and a Public Information Notice (PIN), summarizing the views of the Executive Board as expressed during its June 16, 2008 discussion of the staff report on issues related to the Article IV consultation and the IMF arrangement, respectively.

- $\quad$ A statement by the Executive Director for Benin.

The documents listed below have been or will be separately released.

Letter of Intent sent to the IMF by the authorities of Benin*

Memorandum of Economic and Financial Policies by the authorities of Benin*

Technical Memorandum of Understanding*

*Also included in Staff Report

The policy of publication of staff reports and other documents allows for the deletion of market-sensitive information.

Copies of this report are available to the public from

International Monetary Fund • Publication Services

$70019^{\text {th }}$ Street, N.W. • Washington, D.C. 20431

Telephone: (202) 623-7430 • Telefax: (202) 623-7201

E-mail: publications@imf.org • Internet: http://www.imf.org

Price: $\$ 18.00$ a copy

\section{International Monetary Fund Washington, D.C.}





\title{
INTERNATIONAL MONETARY FUND
}

\section{BENIN}

\section{Staff Report for the 2008 Article IV Consultation, Fourth Review Under the Three- Year Arrangement Under the Poverty Reduction and Growth Facility, and Request for Augmentation of Access}

\author{
Prepared by the African Department \\ (In consultation with other departments)
}

Approved by Robert J. Corker and Anthony Boote

May 30, 2008

- Economic growth is recovering, but price stability has been threatened by the surge in world food and oil prices. The pace of structural reforms remains slow.

- Benin's three-year Poverty Reduction and Growth Facility (PRGF) arrangement (10 percent of quota) was approved on August 5, 2005; the third review took place on June 11, 2007 and the arrangement was extended until August 4, 2009. The authorities are requesting an augmentation of access to deal with rising food and oil prices. If approved, total access will rise to SDR 15.48 million (25 percent of quota) of which SDR 3.52 million has been disbursed so far. An additional SDR 10.17 million, including SDR 9.29 million (15 percent of quota) in higher access, will become available upon completion of this review.

- The last Article IV consultation was completed on November 27, 2006; discussions on the 2008 Article IV consultation and fourth PRGF review were conducted in Cotonou March 3-17, 2008. The staff team met His Excellency President Boni Yayi; The Honorable P. Koupaki, Minister of Development, Prospective and Public Policy Assessment; The Honorable S. Lawani, Minister of Economy and Finance; Mr. M. de Souza, National Director for the Central Bank of West African States (BCEAO); and other senior officials. The staff team comprised Messrs. Matungulu (head), Youm, Samake, Dwight, Guerami (all AFR), and Yao (resident representative). Mr. G. K. Mpatswe, Advisor to the Executive Director, attended some of the meetings. The mission worked with parallel World Bank teams and met with representatives of the donor community, the private sector, and Benin's main civil service unions.

- Benin, a member of the West African Economic and Monetary Union (WAEMU), has accepted the obligations under Article VIII and maintains an exchange system free of restrictions on payments and transfers for current international transactions.

- The discussions reviewed progress on the PRGF-supported program and assessed economic performance and prospects focusing on the challenges of preserving macroeconomic stability while increasing pro-poor and pro-growth spending and improving competitiveness to accelerate growth and facilitate progress toward the MDGs. 
Executive Summary

I. Background. .5

II. Recent Economic Developments and Program Performance............................................5

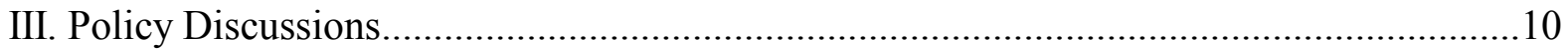

A. Medium-Term Macroeconomic Objectives .................................................... 10

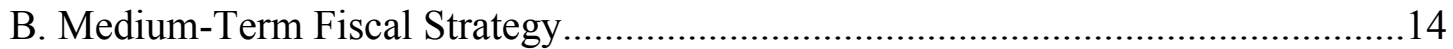

C. Improving Competitiveness and Promoting the Private Sector ............................18

IV. Fourth PRGF Review, Capacity to Repay the IMF and Monitoring of the Program........22

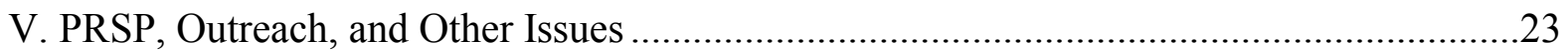

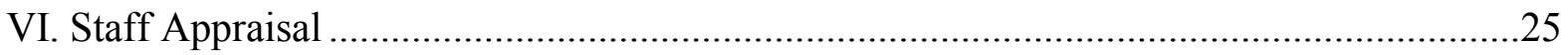

\section{Boxes}

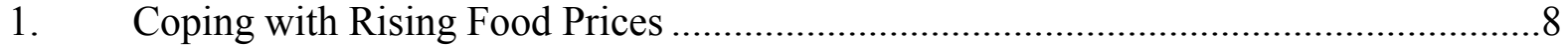

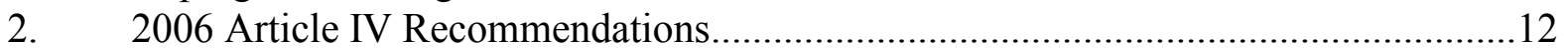

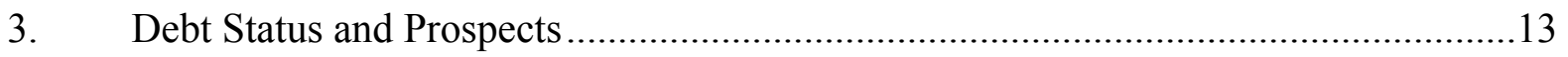

Text tables

1. Selected Macroeconomic Indicators, 2008-11 .................................................14

2. WAEMU: Members' Achievement of Convergence Criteria, 2007.........................15

3. Banking and Financial Prudential Indicators: Number of Banks in Compliance ........22

Figures

1. Overview—Recent Economic Developments, 2003-08 …..................................6

2. Constraints to Growth, 2003-08 ….................................................................... 7

3. Fiscal and Monetary Developments, 2003-08 ......................................................

4. Headline, Food, and Nonfood Inflation, 2003M1-2008M3 …...............................13

5. Competitiveness and Real Effective Exchange Rates..............................................19

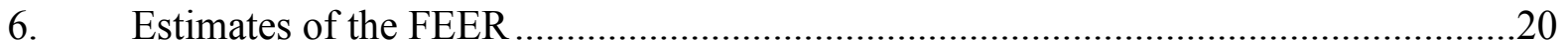

Tables

1. Schedule of Disbursements Under the PRGF Arrangement, 2005-09 ......................27

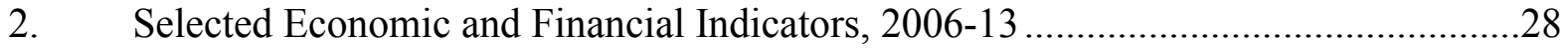

3. Consolidated Central Government Operations, 2006-13 .........................................29

4. Consolidated Central Government Operations, 2006-13 (Percent of GDP)................30

5. Central Government Operations, Quarterly, 2007-09 .......................................... 31

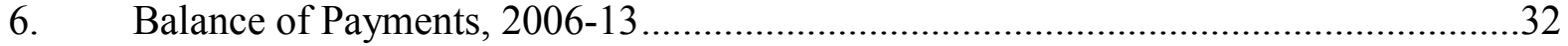




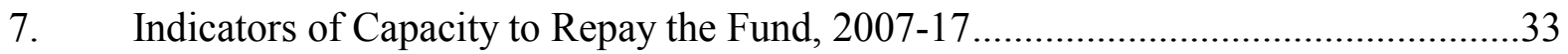

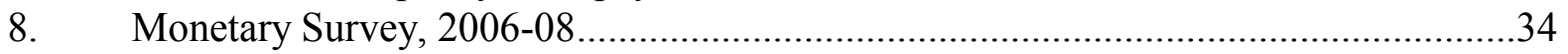

9. Millennium Development Goals ................................................................................35

Appendices

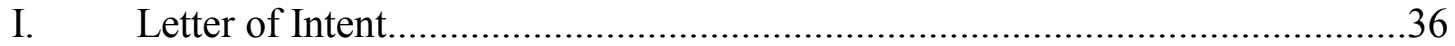

Attachment I: Memorandum of Economic and Financial Policies

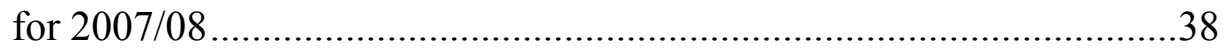

Table 1. Quantitative Performance Criteria and Indicative Targets

for the Period September 2007-December 2008 …..............................48

Table 2. Structural Benchmarks, 2007-08 ........................................49

Attachment II: Technical Memorandum of Understanding ..................50 


\section{Executive Summary}

- In the last two years, Benin has experienced a pickup in growth and low inflation. This has been supported by prudent fiscal policies - both strengthened revenue performance and expenditure discipline - and external debt relief. However, structural weaknesses in the economy have not been addressed. And the external environment has become less favorable with a strengthening CFA franc adding to competitiveness concerns and surging food and fuel prices accentuating a deterioration in the terms of trade.

- Medium-term economic prospects are favorable, but absent accelerated reforms in the cotton and public utilities sectors growth is likely to remain below that required to make more rapid progress to the MDGs.

- The authorities plan to maintain a sound fiscal position and enhance fiscal space for pro-poor spending through further revenue enhancement. Cognizant that progress in meeting fiscal targets could be undermined by tax cuts and subsidies to defray the cost of high food and fuel prices, they are considering more targeted and cost efficient support to the most vulnerable. To meet increased balance of payments financing needs from rising food and oil prices, the authorities have requested an augmentation of access to Fund resources (by 15 percent of quota).

- Effective use of fiscal space and borrowing space in the medium term will require improvements in public expenditure management, particularly as regards capital spending. Public borrowing on concessional terms is needed to maintain debt sustainability.

- While the real exchange rate appears broadly in line with fundamentals, competitiveness should be strengthened. There is broad agreement that structural reform is the remedy.

- The authorities' plans to reform the cotton and utilities sectors are moving slowly. These are crucial sectors for the economy and need to become more dynamic.

- Staff recommends completion of the fourth review and augmentation of the access level under the arrangement to 25 percent of quota. However, while macroeconomic targets have been all met, the slowness of structural reform implementation remains a cause for concern and detracts from program performance. 


\section{BACKGROUND}

1. Benin's macroeconomic performance continues to improve, but progress in addressing core economic vulnerabilities has been slow. A much-publicized acceleration of the structural reform agenda has not materialized, and competitiveness has been undermined by a real appreciation of the effective exchange rate, deterioration in the terms of trade, and some weakening in the business environment. More recently, Benin has had to cope in addition with the surge in world food prices. In April's local elections, President Boni Yayi had mixed success in strengthening his mandate to implement economic reforms.

\section{Recent Economic Developments and Program Performance}

2. Economic performance has been broadly satisfactory since the last Article IV report was issued in 2006, with growth continuing to recover from its 2001-05 slowdown (Figures 1 and 2). Preliminary data put real GDP growth at 4.6 percent in 2007, up from an annual average of 3.4 percent in 2005-06, underpinned by brisk activity in the port, transport and commerce sectors on the strength of enhanced Cotonou port competitiveness; and by a favorable food harvest. These factors countered the adverse impact of a regional energy crisis and lower-than-programmed cotton output.

\section{World food price inflation is sparking an uptick in consumer prices}

(Figure 4). As a result of good weather and comfortable local food availability in 2007, average inflation decelerated to 1.3 percent (3.8 in 2006), below the West African Economic and Monetary Union (WAEMU) threshold of 3 percent; this helped to moderate appreciation of the real effective exchange rate (REER). However, a spike in world food prices before the New Year's celebrations prompted the authorities to impose price controls (Box 1). These did not prevent food prices surging by 8 percent in the first quarter of 2008 .

\section{The external current account deficit widened because of terms of trade deterioration and real currency appreciation. However, thanks to large inflows, mostly of official capital grants, the balance of payments recorded a sizable surplus, keeping official reserves at about 15 months of imports.}

\section{Fiscal performance exceeded expectations in several respects although} public investment lagged. At 3 percent of GDP, the surplus on the narrowly defined primary fiscal balance was 2 percentage points above target. Key fiscal developments were: 


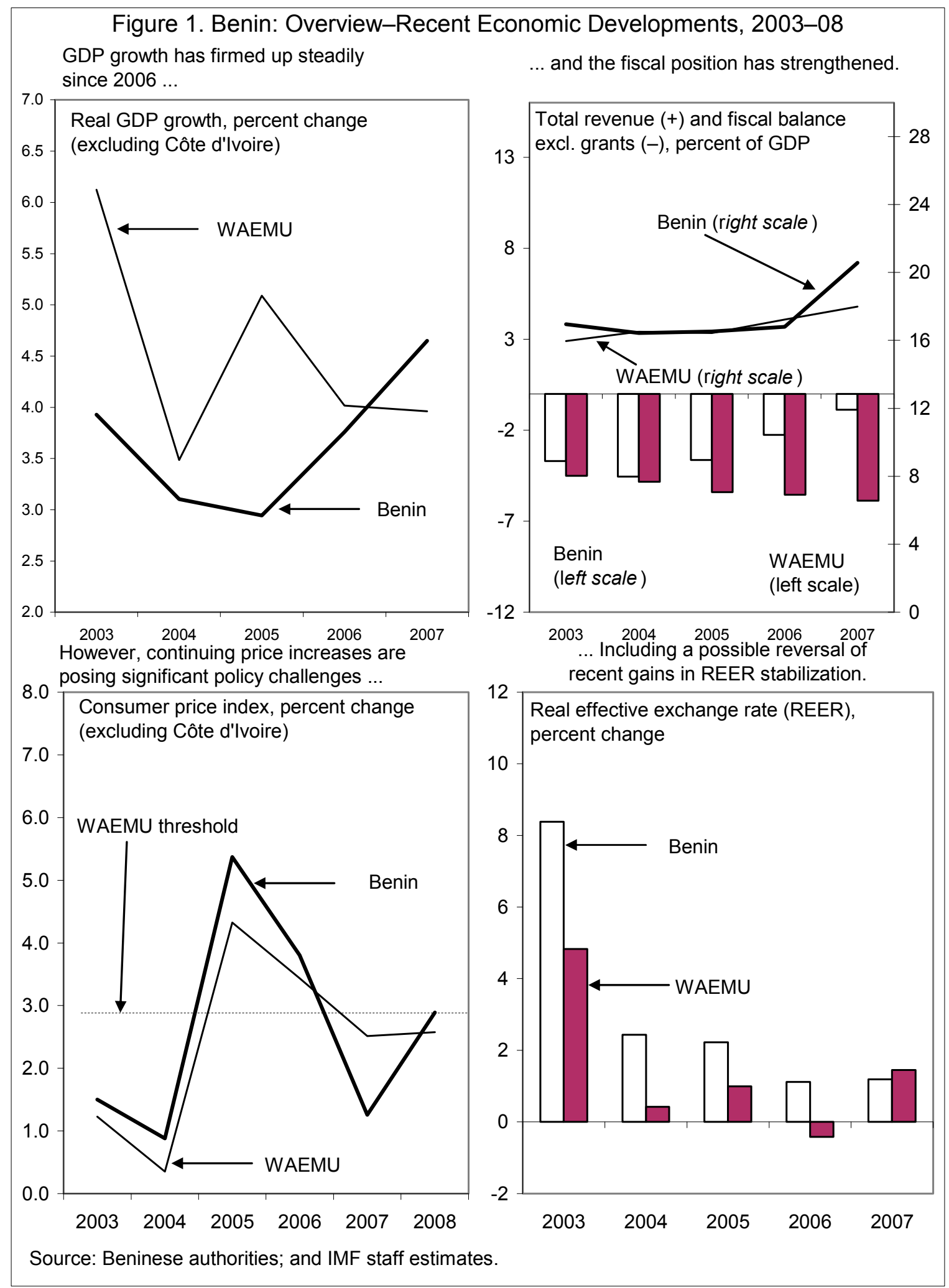


Figure 2. Benin: Constraints to Growth, 2003-08

Growth is below the WAEMU average, constrained by ...
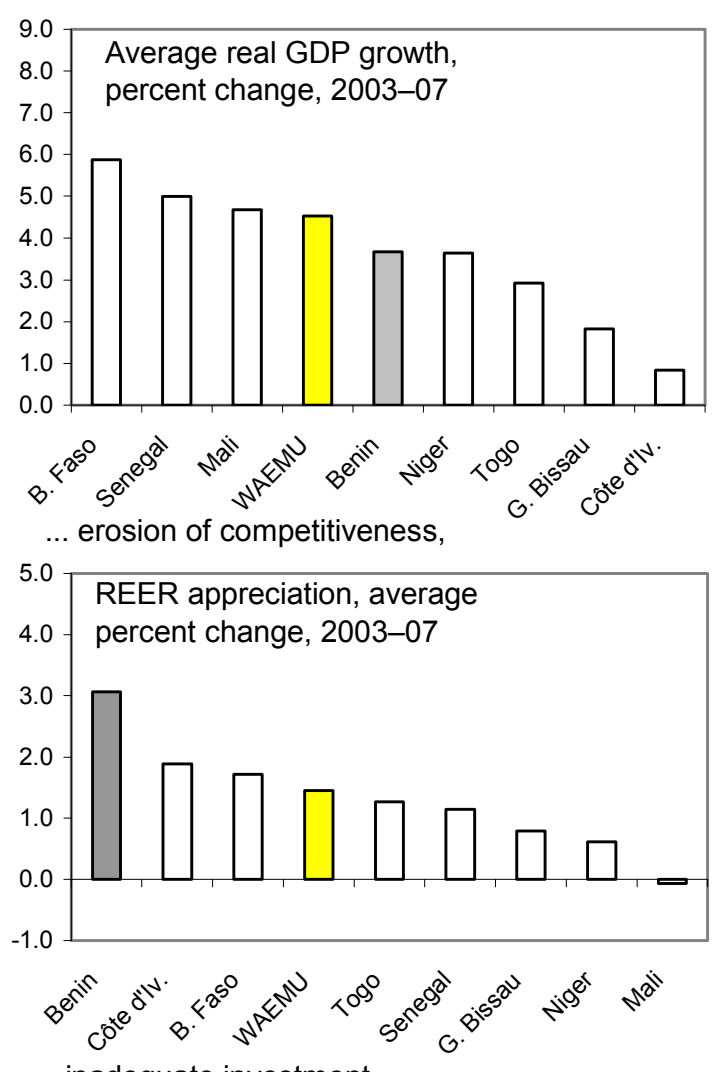

... inadequate investment,

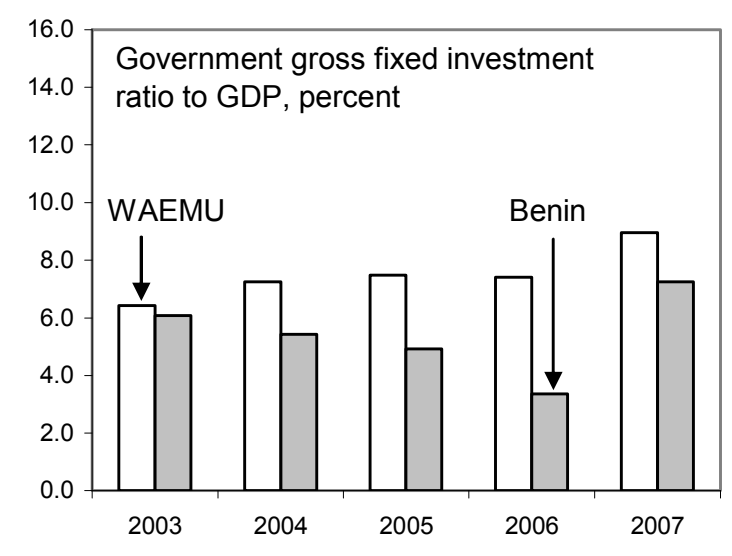

... a difficult energy situation,

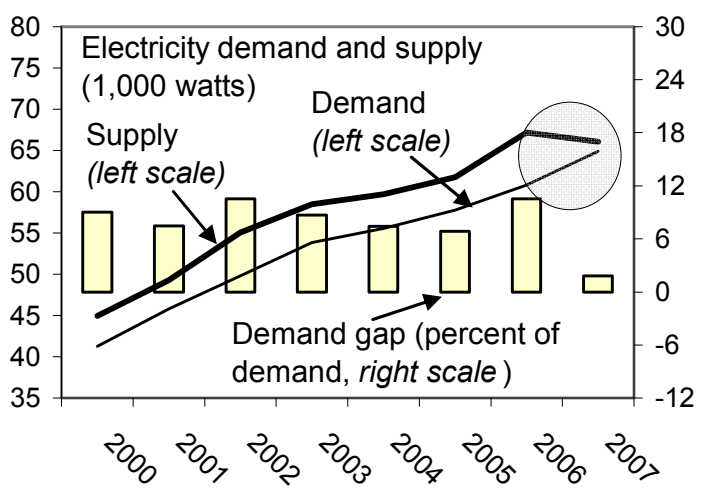

... persistent terms of trade deterioration,

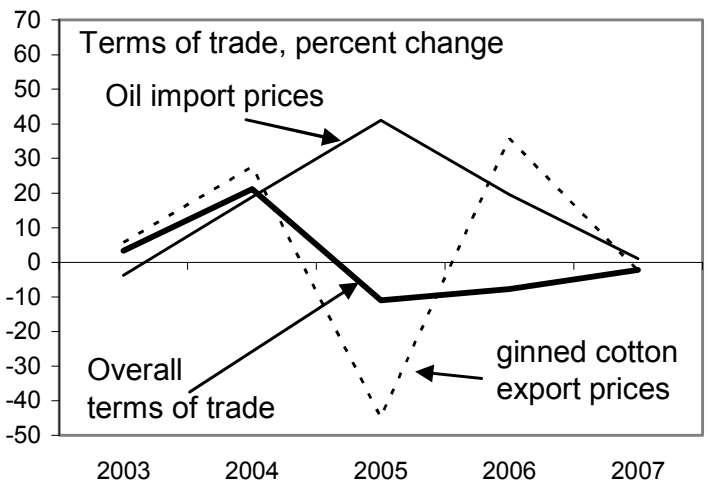

... and a poor business environnement.

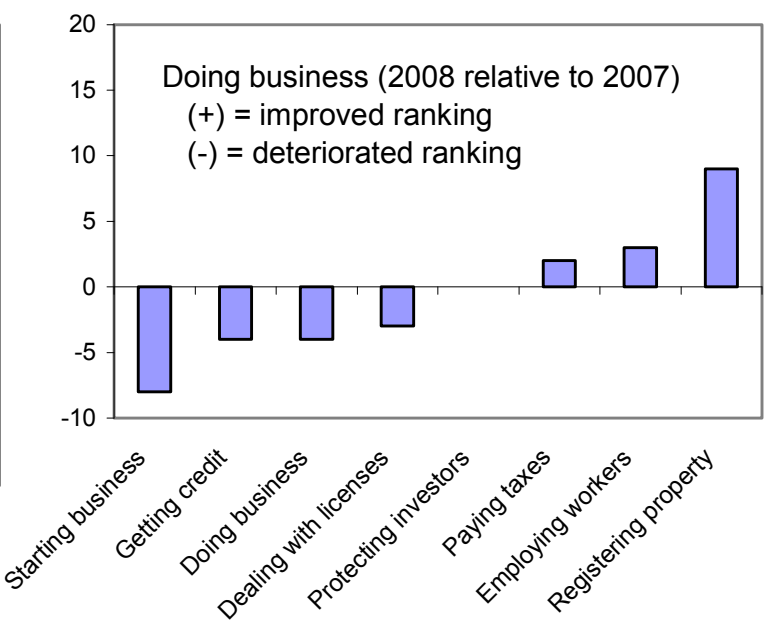

Source: Beninese authorities; and IMF staff estimates. 


\section{Box 1. Benin: Coping with Rising Food Prices}

On December 8, 2007, the Government of Benin introduced fiscal measures to address rising food prices (see paragraph 19 below). The measures were initially intended to last through mid-March 2008; they have since been extended to July and are likely to remain in place through year-end. They consist of

- Elimination of customs tariffs for pasta, tomato paste, and sweetened condensed milk; and

- Reduction of customs fees - using below-market reference prices for taxation purposes - for refined sugar, rice, wheat and wheat powder, corn and maize, and soybeans.

Under the arrangement, retail prices are derived by downwardly adjusting costbased prices to reflect granted tax relief. 
- Better revenue mobilization, with tax revenue nearly reaching the WAEMU target of 17 percent of GDP for the first time and the authorities collecting 2.3 percent of GDP in one-off nontax receipts from cellular phone licenses.

- Better control of spending on goods and services, including the wage bill; overruns on payments to state-owned energy companies to contain increases in electricity tariffs and petroleum product prices; and underspending on domestically funded capital projects (68 percent) due to limited absorptive capacity.

- A hefty net increase in government deposits with the banking system (5.1 percent of GDP), reflecting limited use of investment funds raised in the WAEMU financial market ${ }^{1}$ and difficulties in translating fiscal space into more ambitious pro-growth spending.

- Tightened governance in the revenue agencies and determined implementation of IMF Fiscal Affairs Department technical assistance (TA) recommendations on revenue management, mainly directed to tax and customs administration - especially at the large-taxpayer unit.

- Concerted efforts to begin addressing problems in infrastructure and project management, including accelerated procurement and compression of time for contract preparation and award.

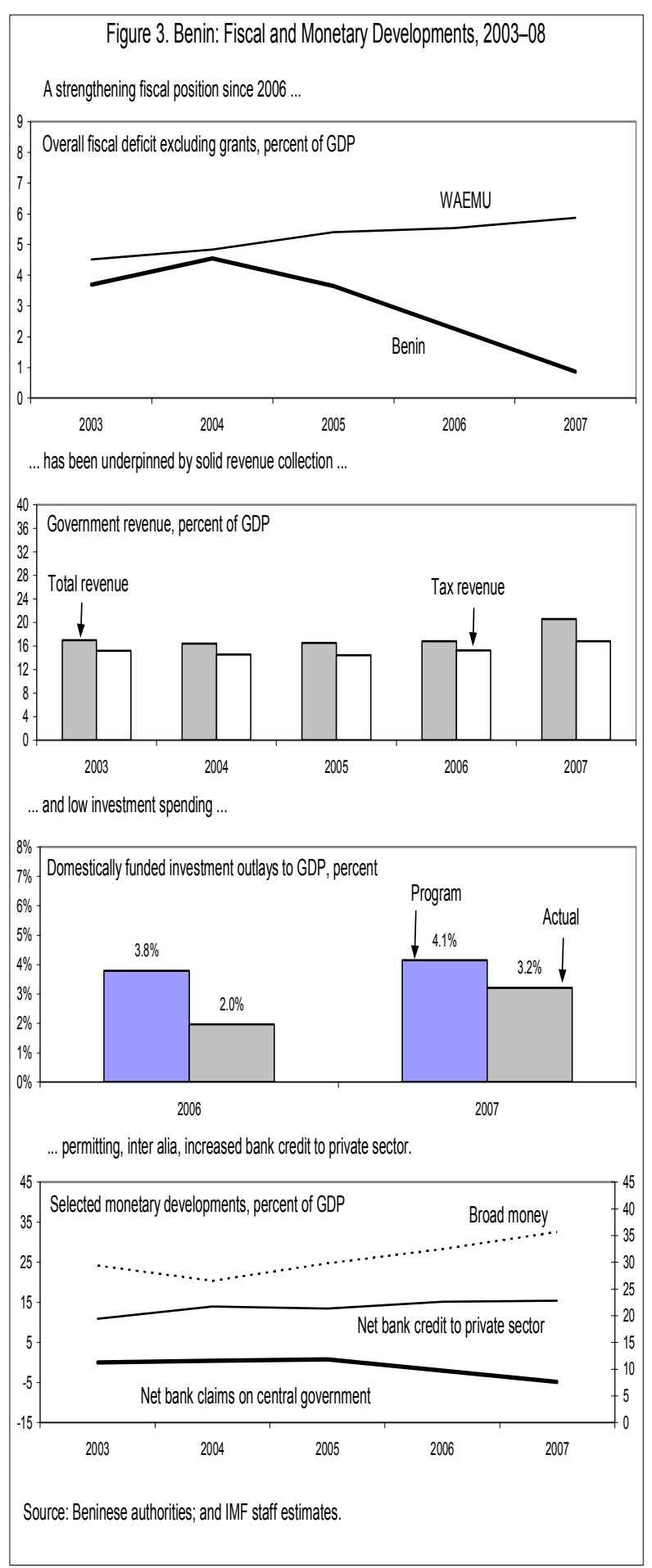

\section{Broad money rose by 18 percent, substantially above nominal GDP growth,} driven mostly by donor-supported increases in net foreign assets. Consistent with the

\footnotetext{
${ }^{1}$ Most of the loan proceeds from the regional financial market were not used because of delays in finalizing infrastructure projects.
} 
improved budgetary situation and related increases in Treasury deposits in the banking system, net bank credit to the government again contracted, permitting a 26 percent expansion of credit to the private sector, mostly for commerce, transportation, and telecommunications activities. The credit expansion prompted the authorities to keep the reserve ratio at 15 percent (the highest in the WAEMU) to insure against inflationary and capital flight repercussions.

7. Performance on the program was generally satisfactory (MEFP, Tables 1 and 2). All quantitative benchmarks for end-September and performance criteria for end-December 2007 were observed by large margins. However, only two of four structural benchmarks for the second half of 2007 were implemented, one with a delay. The single taxpayer identification number system was introduced and a study of the efficiency of customs completed before year-end, but audit of PFM information systems and a draft strategy for reforming the civil service pension fund were not completed by year-end. The authorities are taking steps to complete these measures before end-2008.

\section{Policy Discussions}

8. The Benin authorities have maintained macroeconomic stability but face major policy challenges in raising growth to address poverty. While revenue performance has improved markedly in these post-HIPC/MDRI years, capacity problems have limited the translation of higher fiscal space into more development spending; and a much-publicized acceleration of the structural reform agenda has not materialized. At the same time, a steady nominal effective appreciation of the euro-pegged CFA franc, deterioration in key areas of the business environment, and reemergence of heavy wage demands are raising competitiveness concerns.

9. With this in mind, discussions concentrated on three topics:

- Medium-term macroeconomic prospects and objectives;

- Fiscal policy and PFM reforms to support growth and poverty reduction while preserving external stability; and

- Structural reforms, including second-generation initiatives, to nurture competitiveness and foster private sector development.

Staff also assessed conditions for completing the fourth PRGF review.

\section{A. Medium-Term Macroeconomic Objectives}

10. Benin's medium-term economic prospects seem generally favorable, although growth is likely to continue to fall short of what is required to rapidly reduce poverty. 
The authorities concurred that growth will remain heavily dependent on performance in the port and cotton sectors, with a pickup in construction and public works supporting domestic demand as the government rebuilds the economic and social infrastructure. Cotton production and export growth are projected to remain below potential in view of slow progress in sector reform (see below); and imports of oil and capital goods would grow only moderately in real terms due to capacity limitations. Consistent with likely developments in world oil and staple food prices, the terms of trade are projected to deteriorate moderately. Absent a marked acceleration of structural reforms, the main elements of the medium-term macroeconomic framework are:

- Annual average real GDP growth of 51/2 percent through 2011; with average inflation at the top of the WAEMU ceiling of 3 percent.

- A generally sound external position - a projected current account deficit of 6-7 percent of GDP seems sustainable given expected financing - and manageable debt service obligations (Box 3).

- A stability-oriented, narrowly defined annual primary fiscal surplus of 1 percent of GDP, which will accommodate a gradual increase in pro-growth spending. 


\section{Box 2. 2006 Article IV Recommendations}

\begin{tabular}{|l|}
\hline \multicolumn{1}{|c}{ Advice } \\
\hline$\bullet \quad \begin{array}{l}\text { Improve revenue administration and } \\
\text { expenditure management to achieve fiscal } \\
\text { consolidation and increase pro-poor } \\
\text { spending. }\end{array}$
\end{tabular}

- $\quad$ Continue efforts to reduce nonperforming loans and avoid loan concentration risks in financial institutions.

- $\quad$ Give due consideration to external debt sustainability in new borrowing.

- $\quad$ Enhance competitiveness through reforms in the parastatal sector.

- $\quad$ Pursue reforms to address weaknesses in the judicial system, modernize land tenure, and facilitate access to financial services for small and medium-sized enterprises.
Status

The authorities have improved revenue collection and the fiscal position. However, limited absorptive capacity and poor expenditure management frustrates their ambition to increase spending on infrastructure and pro-poor projects.

Nonperforming loans rose to around 10 percent of banks' portfolios. Deterioration of the portfolio of microfinance institutions was more severe. Benin is bound by the decision taken by WAEMU institutions to raise, starting January 1, 2008, minimum capital requirement to CFAF 1 billion for nonbank financial institutions and CFAF 5 billion for banks.

External borrowing has been limited to concessional credits. Domestic borrowing has increased dramatically; however, including funds raised nonconcessionally on the WAEMU financial market.

Parastatal reform was set back by the unsuccessful privatization of the ginning company, SONAPRA. Preparation for government disengagement from other public enterprises is taking longer than anticipated.

Preparation for second-generation reforms in these areas is proceeding, financed for the most part by MCA-Benin. 


\section{Box 3. Benin : Debt Status and Prospects}

Debt relief from the HIPC Initiative in 2003 and MDRI in 2006 has greatly reduced Benin's debt. The external public debt-to-GDP ratio fell to 12 percent in 2006 from about 59 percent in 2001. Domestic public debt is about 3.6 percent of GDP.

Benin's risk of debt distress is moderate. All indicators in the 2007 DSA baseline scenario are far below policy-dependent thresholds. However, the NPV of debt-to-export threshold is breached in scenarios that incorporate lower growth, more volatile cotton production, and less generous financing terms. Fiscal sustainability analysis confirms these results and highlights concerns about the cost of heavy domestic borrowing at high interest rates and shorter maturities. The authorities could reduce risks and safeguard debt sustainability through determined efforts to continue structural reforms (including measures to spur private sector participation in development); address absorption constraints; and manage debt prudently (Country Report No. 08/19).

\section{Within the medium-term framework the authorities see growth rising to}

\section{3 percent in $\mathbf{2 0 0 8}$ despite the heightened risks of a difficult global environment.}

Among factors underpinning the modest growth acceleration are

- Robust port-related service activities, based on expanded merchandise handling capacity as new cranes go into service; modern management practices facilitated by the recent recruitment of an external port expert and independent auditor; and streamlined operations as the port's one-stop window is activated.

- Favorable cotton prospects, in view of timely importation and distribution of fertilizers without government interference in the awarding of contracts.

- Increased spending on infrastructure rehabilitation and

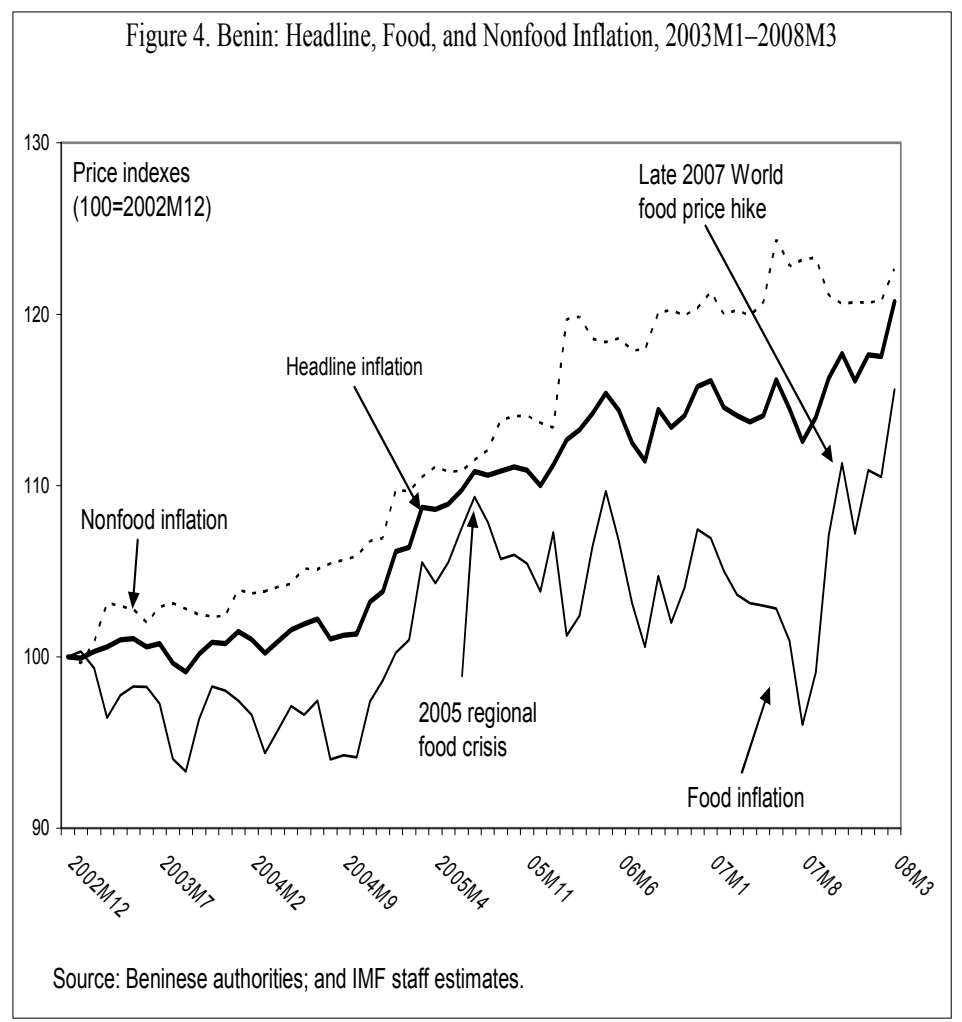


activity in construction and public works - although this is being frustrated by supply bottlenecks, such as the limited availability of cement and other construction materials and a scarcity of skilled workers.

Continuing upward pressures on oil and food prices are expected to ratchet inflation up to the upper bound of the WAEMU target (possibly beyond in case of sustained world oil and food price increases). The supply of domestic foodstuffs is generally adequate.

Text Table 1. Benin: Selected Macroeconomic Indicators, 2008- 11 (Annual change, unless otherwise indicated)

\begin{tabular}{|c|c|c|c|c|c|c|c|}
\hline & \multicolumn{2}{|c|}{2008} & \multicolumn{2}{|c|}{2009} & \multicolumn{2}{|c|}{2010} & \multirow{2}{*}{$\frac{2011}{\text { Proj. }}$} \\
\hline & $\begin{array}{r}\text { CR } \\
08 / 19 \\
\end{array}$ & $\overline{\text { Proj. }}$ & $\begin{array}{r}\text { CR } \\
08 / 19 \\
\end{array}$ & Proj. & $\begin{array}{r}\text { CR } \\
08 / 19 \\
\end{array}$ & $\overline{\text { Proj. }}$ & \\
\hline Real GDP & 5.4 & 5.3 & 5.7 & 5.6 & 5.7 & 5.8 & 6.0 \\
\hline Inflation (end-year) & 2.7 & 5.5 & 2.7 & 2.7 & 2.9 & 2.9 & 2.9 \\
\hline External current account balance ${ }^{1}$ & -6.1 & -7.5 & -6.0 & -7.2 & -5.9 & -6.9 & -6.6 \\
\hline Narrow primary budget balance ${ }^{1}$ & 1.0 & 0.5 & 1.0 & 1.0 & 1.1 & 1.0 & 1.0 \\
\hline Overall fiscal balance ${ }^{1,2}$ & -4.6 & -5.1 & -4.4 & -4.5 & -4.3 & -4.5 & -4.4 \\
\hline \multicolumn{8}{|l|}{ Memorandum items: } \\
\hline Production of cotton ( 1,000 of tons $)^{3}$ & 346.8 & 312.5 & 384.2 & 346.2 & 425.6 & 383.5 & 424.9 \\
\hline Terms of trade & 6.4 & -5.0 & 5.1 & 1.2 & -2.7 & -0.6 & 0.0 \\
\hline Broad money & 8.2 & 8.3 & 9.3 & 8.6 & 8.5 & 9.1 & 9.1 \\
\hline Credit to the nongovernment sector & 7.7 & 6.7 & 9.1 & 7.2 & 8.6 & 7.6 & 8.0 \\
\hline
\end{tabular}

Sources: Benin authorities; and IMF staff estimates and projections.

${ }^{1}$ Percent of GDP excluding grants.

${ }^{2}$ Payment order basis.

${ }^{3}$ For 2007-08, 2008-09, and 2009-10 seasons.

12. The authorities expressed concern that developments in the global economy were adding risks to Benin's outlook, at least in the short term. They especially feared a possible further deterioration in the terms of trade and the impact on real domestic incomes, prices, and competitiveness - a concern amplified by continued strengthening of the CAF franc. Other risks identified were unsettled energy prospects, weather-related shocks to agriculture (including cotton production), uncertainties about relations with main trading partners, and limited absorptive and institutional capacity. They reiterated their commitment to growth-supporting reforms to insure against the risks. On the positive side, it was agreed that demand from Nigeria's oil-based economy, which is expected to sustain activity in the port and transportation sectors as well as in agriculture and industry, would counterbalance some of the risks.

\section{B. Medium-Term Fiscal Strategy}

13. The mission discussed the outline of a pro-growth fiscal policy for the postMDRI era. Envisaged policy actions aim at further expanding government domestic resources by raising the revenue ratio to 19.4 percent of GDP by 2011, and implementing more ambitious pro-growth and pro-poor spending programs without jeopardizing recent 
gains in economic stabilization. ${ }^{2}$ In pursuit of the latter objective, the authorities will continue to meet the WAEMU convergence criterion on the narrowly defined primary fiscal balance - containing the overall fiscal balance (excluding grants) to around $4 \frac{1}{2}$ percent of GDP and keeping demand-induced inflationary pressures in check. This would help limit total debt (domestic and external) to below 20 percent of GDP by 2011; 80 percent of identified government financing needs (averaging an estimated 2 percent of GDP) would be filled with grants and the rest with concessional loans, consistent with recommendations from the 2007 DSA.

\begin{tabular}{|c|c|c|c|c|c|}
\hline & $\begin{array}{r}\text { Basic Fiscal } \\
\text { Balance to GDP }\end{array}$ & $\begin{array}{r}\text { Average } \\
\text { Consumer Price } \\
\text { Inflation } \\
\end{array}$ & $\begin{array}{r}\text { Debt ratio } \\
\text { to GDP }\end{array}$ & $\begin{array}{c}\text { Change in } \\
\text { Domestic Arrears }\end{array}$ & $\begin{array}{r}\text { Change in } \\
\text { External Arrears }\end{array}$ \\
\hline Target & ( $\geq 0$ percent) & ( $\leq 3$ percent $)$ & ( $\leq 70$ percent) & ( $\leq 0$ percent $)$ & ( $\leq 0$ percent $)$ \\
\hline Benin & 0.6 & 1.3 & 12.6 & -30.9 & 0.0 \\
\hline Burkina Faso & -6.0 & -0.2 & 20.8 & 0.0 & 0.0 \\
\hline Côte d'Ivoire & -0.4 & 2.1 & 104.3 & -50.4 & 271.8 \\
\hline Guinea Bissau & -12.6 & 3.8 & 283.7 & 6.6 & 10.6 \\
\hline Mali & -1.1 & 2.5 & 23.9 & 0.0 & 0.0 \\
\hline Niger & -0.2 & 0.1 & 14.9 & -14.8 & 0.0 \\
\hline Senegal & -2.9 & 5.9 & 43.8 & 0.0 & 0.0 \\
\hline Togo & -2.8 & 1.0 & 86.0 & 10.9 & 38.6 \\
\hline WAEMU & -1.7 & 2.2 & 57.6 & -95.8 & 321.0 \\
\hline Number of countries violating & 8 & 2 & 3 & 2 & 4 \\
\hline
\end{tabular}

Sources: WAEMU, BCEAO, and IMF staff estimates.

${ }^{1}$ Estimates.

\section{Revenue-enhancing measures will be directed to making tax and customs} administration more efficient and rationalizing the tax system. Authorities noted that their implementation of FAD recommendations in revenue administration had yielded good results. The next areas of attention in revenue administration would be to

- Effectively implement the new single taxpayer identification number system-which would enhance taxpayer data exchanges between the General Tax and Customs Directorates;

- Further reinforce customs IT capacity in regional offices; and

- Operate a one-stop window at the Port of Cotonou, which includes putting in place a consolidated electronic billing system for port services, with financial and technical support from the US-funded MCA-Benin.

\section{The authorities intend, with FAD technical assistance, to review Benin's domestic tax structure. ${ }^{3}$ In particular, they are seeking to address competitiveness}

\footnotetext{
${ }^{2}$ Because of rapid fiscal consolidation, in 2007 Benin became the only WAEMU member country meeting the convergence criterion on the (non-negative) narrowly defined fiscal balance.

${ }^{3}$ An FAD tax policy mission is expected to be fielded in the second half of June 2008.
} 
difficulties arising from disparities in WAEMU domestic tax rates-e.g., Benin's corporate income tax rate is 35 percent, Senegal's is 25 percent - and substantially enhance domestic tax performance as economic partnership agreements (EPA) are negotiated with Europe at the regional level ${ }^{4}$ and preparations continue on expanding regional integration beyond the WAEMU. The envisaged overhaul of the tax system will be consistent with Benin's fiscal harmonization obligations under the WAEMU.

16. The authorities concurred with staff that spending must continue to be prudent until PFM and project evaluation are improved. Total spending is projected to rise to 23.2 percent of GDP by 2011, from 22 percent in 2007, consistent with the medium-term revenue and fiscal balance objectives under the PRGF-supported program. However, while committed to keeping Benin's debt sustainable, the authorities considered a less conservative spending target to accelerate their infrastructure rehabilitation program while external budget support continues and borrowing is readily available in the regional financial market. They agreed, however, that until Benin's limited absorptive capacity is addressed, a cautious approach to spending growth is preferable in the short term, with reduced net credit to the government helping to improve borrowing prospects for the private sector.

\section{Better management of public investment is key to successfully implementing} more ambitious pro-growth expenditure programs. The rate of execution of domestically funded investment outlays (DFIOs) inched up to 68 percent in 2007 (from 57 percent in 2006) as project preparation and procurement activities were exceptionally accelerated late in the year under President Yayi's direct supervision. The authorities attributed lackluster performance in this area to scarcity of working materials and domestic expertise, poor coordination of entities managing public investment, and to weak financial management systems. They are therefore beefing up operating resources at the disposal of spending ministries and units and intend bi-monthly cabinet consideration of reports on the execution of DFIOs, which would be posted on the Web site of the Office of the President of the Republic (MEFP, paragraph 28). Staff noted that public-private sector partnerships in infrastructure rehabilitation and building are virtually nonexistent in Benin. They encouraged the authorities to request World Bank TA on this and on drafting a comprehensive strategy to expand absorptive capacity.

\section{The fiscal program for $\mathbf{2 0 0 8}$ targets a moderate increase in spending to support} growth and poverty reduction. Without the exceptional nontax payments received from cellular phone companies in 2007 , and taking account of the impact of the price-moderating

\footnotetext{
${ }^{4}$ A comprehensive assessment of the revenue impact has yet to be made at the national level, but the authorities concurred that an appropriate policy response would include the introduction of compensating revenue measures and tax reforms to broaden the tax base.
} 
fiscal measures, revenue collection is projected to decline to 18.4 percent of GDP (20.6 percent in 2007). With total expenditure (excluding interest payments and foreignfinanced investment) rising to 17.9 percent of GDP, the primary fiscal surplus would decline to $1 / 2$ percent of GDP (from 3 percent in 2007); and the overall fiscal deficit (cash basis, excluding grants) would be contained at 4.4 percent of GDP. Beyond contributions from the European Union, the World Bank and the African Development Bank, the authorities have requested additional resources from the Fund ( 0.2 percent of GDP) to cover identified financing needs (Tables 1, 2 and 4, and paragraph 29). They are also discussing additional financing with other multilateral and bilateral donors.

\section{Rising food and oil prices pose some risk to fiscal targets and are causing a} deterioration of the external position. The limited tax cuts and subsidies entail a revenue loss estimated at 1 percent of GDP and include CFAF 11 billion ( 0.4 percent of GDP) in transfers to public utilities to contain anticipated energy cost increases. If the measures are expanded or are not adequately implemented, the revenue loss could be much higher than currently anticipated, which would cause the program's fiscal target to be missed. In the external sector, the current account deficit (excluding grants) is projected to widen to 7.5 percent of GDP, from 6.9 percent in 2007(MEFP, paragraph 28). The authorities have stressed that beyond the initial safeguard measures, sustained price increases would require introduction of well-targeted social safety nets, with donor support if needed; they concurred that to avoid jeopardizing domestic supply of affected products, enhanced price flexibility would be needed in the medium to long term (MEFP, paragraph 13).

\section{In 2008 revenue mobilization efforts will be geared at reinforcing tax and} customs administration, and nonpriority expenditures will be rigorously monitored to ensure that fiscal targets are met. Targeted increases in tax receipts will be driven by governance improvements in the revenue agencies and by more effective tracking of taxpayers as the new identification number becomes operational. Efforts will be stepped up to control smuggling and better track exemptions. Domestically financed investment, focused on priority sectors and taking into account absorptive capacity constraints, is projected at CFAF 100.4 billion (3.5 percent of GDP, compared with 3.2 percent in 2007).

21. The authorities remain concerned about pressures on public sector wages. Under pressure from civil service trade unions, the government agreed a 25 percent increase in teacher base salaries, effective July 2008. As a result, the wage bill is projected to rise to 5.7 percent of GDP (from 5.4 percent in 2007). While personnel outlays would remain within the WAEMU target of 35 percent of tax revenue in 2008, and are projected to decline to an annual average of 5.6 percent of GDP during 2009-2011, the authorities reaffirmed their preference to keep for now a wage ceiling as program conditionality to manage wage demands from public sector unions. Staff stressed that improvements in payroll systems would be more effective, and encouraged the authorities to eliminate the ceiling as progress is 
made on wage management. It further noted in this context that finalizing the strategy for reforming the civil service pension fund and ensuring an early implementation of related recommendations will contribute to preserving medium-term budget viability; and urged the authorities to undertake this reform without delay.

\section{Improving Competitiveness and Promoting the Private Sector}

\section{Staff argued that, as a small coastal economy with a fixed exchange rate, Benin} must be especially ambitious in implementing structural reforms to preserve competitiveness. In this regard, staff analysis points to a poor competitiveness profile for the country $^{5}$ :

- As of 2007 Benin's REER had appreciated 37 percent since the 1994 devaluation of the CFA franc, more than any other WAEMU member. During the same period, relative productivity gains have been modest — per capita output rose 20 percent, not exceptional relative to the WAEMU countries and other trading partners.

- Survey measures relevant to competitiveness rank Benin in the bottom 20 percent worldwide (although it is one of the most competitive countries in the WAEMU). It ranked 151 out of 178 in the World Bank's 2008 Doing Business Indicators and 108 out of 131 in the World Economic Forum's 2008 Global Competitiveness Index. Areas in need of urgent reform are contract enforcement, paying taxes, inadequacies in education, and infrastructure.

\footnotetext{
${ }^{5}$ For details of this analysis, see the accompanying Selected Issues Paper.
} 
Figure 5. Benin: Competitiveness and Real Effective Exchange Rates

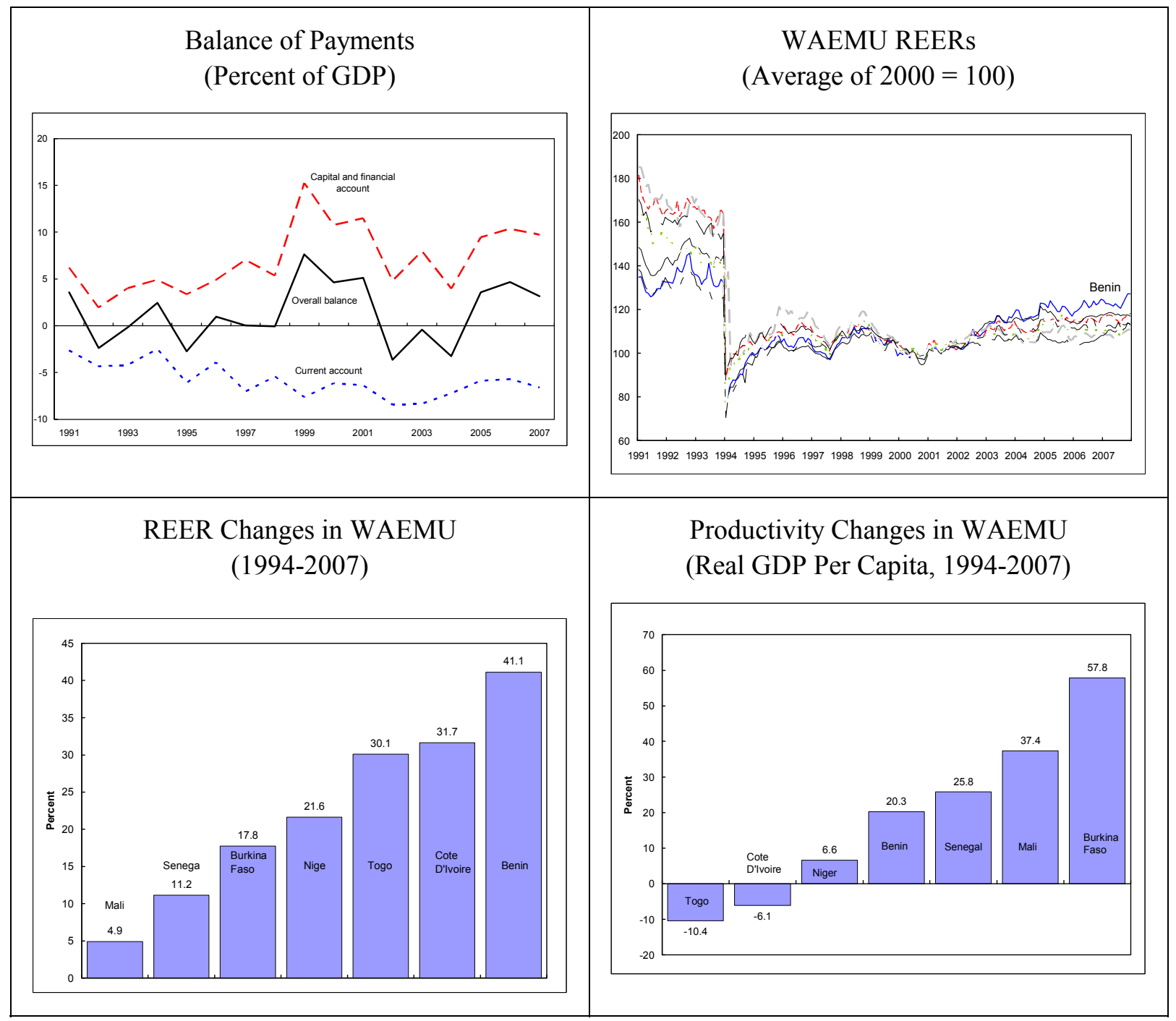

23. However, a variety of macroeconomic analyses of the balance of payments and the REER suggest that Benin's current account balance and exchange rate are on balance broadly in line with fundamentals:

- $\quad$ The current account deficit is comfortably financed by inflows through the capital and financial accounts, in particular project grants and loans, private capital, and inflows to commercial banks, making Benin a net contributor to BCEAO reserves. 
- $\quad$ Econometric estimates of the fundamental effective exchange rate (FEER) ${ }^{6}$ suggest the REER is in line with fundamentals.

Figure 6. Benin: Estimates of the FEER

(Average of $2000=100$ )

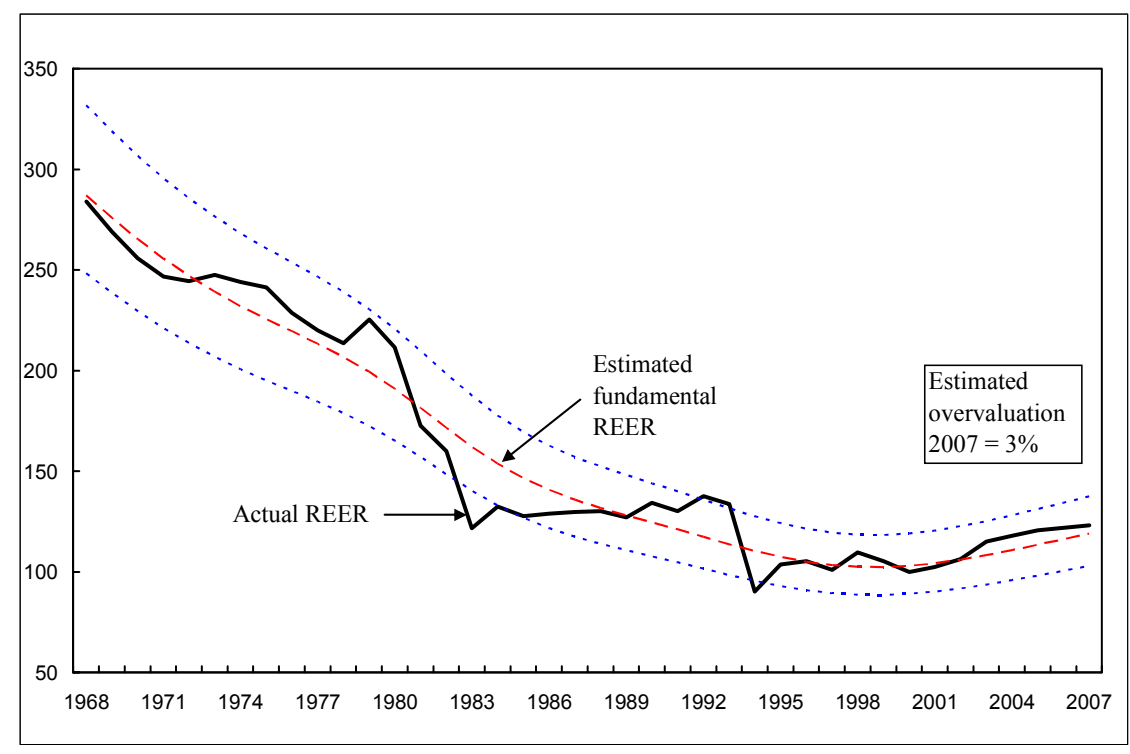

- The macroeconomic balance approach suggests Benin's current account deficit is in line with the norm for a low income African country with substantial aid inflows.

- However, longer-run external considerations, based on sustainable levels of foreign direct investment as well as portfolio and debt flows, suggest that the current account deficit might need to decline to 3-5 percent of GDP, from its underlying level of 6 percent of GDP, which would require a real depreciation of 5-12 percent $^{7}$.

In conclusion, the current account and real exchange rate appear reasonably sustainable. However, other indicators suggest that Benin needs to do more to boost competitiveness. As the nominal exchange rate is fixed, this will require greater efforts to address structural and institutional shortcomings.

\footnotetext{
${ }^{6}$ The underlying current account balance was obtained by adjusting the observed current account for temporary factors through two approaches, including applying filters to the data using a five-year moving average and the Hodrick-Prescott filter (see footnote 5 above).

${ }^{7}$ Estimated REER elasticities of the current account were used to determine the extent of REER depreciation required to adjust the actual current account balance toward an NFA-stabilizing level (see footnote 5 above).
} 


\section{The structural reform agenda}

24. Cognizant of Benin's tenuous competitiveness, the authorities renewed their commitment to structural reforms to improve the business environment and reinvigorate growth. Staff urged them to address continuing delays especially in the cotton, port, and public utilities sectors.

- Cotton. After last year's failed attempt to privatize state-owned ginning factories, the government has undertaken a review of economic and institutional constraints in the cotton sector with a view to drafting a new sector strategy. Beyond issues relating to state disengagement from commercial activities, the strategy is to (i) revisit the government's role in determining producer prices and in the handling of contracts for the import and distribution of fertilizers and other inputs, and (ii) redefine accordingly the institutional framework governing relations between cotton-sector stakeholders. To enhance ownership, the strategy is being prepared in consultation with all key stakeholders; it is expected to be completed by year-end (a structural benchmark). The mission noted the lack of World Bank technical assistance in drafting the new framework and urged the authorities to secure it soon.

- Port of Cotonou. The authorities reported the recent appointment of an independent auditor for port operations and progress in putting in place a near-concessioning arrangement involving a foreign partner of international repute in port management. The MCA assured staff that a resident port management expert would be posted shortly (end-June 2008 structural benchmark).

- Public utilities reforms are suffering significant delays. Benin Telecoms is now slated to be brought to the point of sale in the second half of 2009; the initial deadline was January 2009. Also, the authorities plan to develop a strategy for state disengagement from the electricity parastatal (SBEE) only after the company's restructuring is completed in December 2009. Consequently, bids for privatization cannot be issued until well after the January 2009 deadline. Staff underscored the competitiveness gains from public utilities reforms in terms of improved service quality and reliability, but also regarding their potential for attracting investments in other major economic sectors. It urged the authorities to ensure that these are accelerated with World Bank support.

25. Other measures planned to enhance competitiveness are initiation of a roadrehabilitation program, preparation of a strategy to diversify the economy, and reform of the land tenure and judicial systems. A new World Bank-supported economic diversification program is seeking to boost activity in export agriculture (based on traditional crops_-bananas, palm oil, and pineapple); transportation and telecommunications; and tourism. The program also aims to raise local production and reduce imports of staple 
foodstuffs, such as manioc and livestock. Steady progress in preparing feasibility studies and sector strategies to address inefficiencies in the land tenure and judicial systems and to improve credit access for small- and medium-sized companies is being made.

\section{The authorities are moving to improve commercial bank compliance with}

prudential indicators. Benin's banking system features high concentration of credit, little portfolio diversification, and considerable maturity mismatch between demand for and supply of long-term financial resources. Moreover, four institutions bore 80 percent of nonperforming loans accounting for 9 percent of total bank loans in 2007. BCEAO, the regional central bank, is phasing in an increase of commercial bank minimum capital from CFAF 1 billion to CFAF 10 billion. The staff noted that compliance with prudential requirements had deteriorated somewhat and urged the authorities to monitor the situation closely.

Text Table 3. Benin: Banking and Financial Prudential Indicators: Number of Banks in Compliance

\begin{tabular}{llrr}
\hline \multicolumn{1}{c}{ Indicators } & Coefficient & $\begin{array}{r}\text { End- } \\
\text { December } \\
2006\end{array}$ & $\begin{array}{r}\text { End- } \\
\text { December } \\
2007\end{array}$ \\
\hline & & & \\
1. Own resources requirement & & $06 / 12$ & $04 / 12$ \\
2. Risk-adjusted own resources & $>=1000$ CFA F million & $09 / 12$ & $08 / 12$ \\
3. Liquidity coefficients & $>=8 \%$ & $08 / 12$ & $08 / 12$ \\
4. Portfolio structure & $>=75 \%$ & $01 / 12$ & $0 / 12$ \\
5. Coverage of medium and long term loans & $>=60 \%$ & $04 / 12$ & $04 / 12$ \\
6. Loan to bank managers & $>=75 \%$ & $11 / 12$ & $09 / 12$ \\
7. Risk concentration & $<=20 \%$ & $09 / 12$ & $03 / 12$ \\
$\quad$ Threshold on global lending & $<=8{ }^{*} \mathrm{FPE}$ & $06 / 12$ & $\ldots$ \\
$\quad$ Threshold on single borrower & $<=75 \%{ }^{*} \mathrm{FPE}$ & & \\
\hline
\end{tabular}

\section{Benin's local BCEAO management expressed firm support for enhanced} financial sector surveillance at the regional level, as advised by a recent WAEMU FSAP mission. Finance ministry and national BCEAO officials are endeavoring to secure early implementation of recent regional agreements on transferring from finance ministries to the WAEMU Banking Commission the power to liquidate or place credit institutions under temporary administration — which should make banking supervision more effective; and making BCEAO the regulator for large microfinance institutions (MFIs). Parliament could ratify these initiatives by year-end.

\section{Fourth PRGF Review, Capacity to Repay the IMF, And Program MONITORING}

28. Conditions for completing the fourth PRGF review have generally been met. In the last two years the authorities have achieved measurable improvements in the public 
finances and presided over a rebound in growth despite a difficult international context and vocal social demands - though economic activity has been less than the program expected. Fiscal performance through March 2008 has been broadly satisfactory, and budgetary prospects for the remainder of 2008 are consistent with understandings the mission reached with the authorities on quantitative performance criteria for end-June and end-December 2008, in line with the 2008 budget (MEFP, Tables 1 and 2; Staff Report, Tables 2, 3, and 4). ${ }^{8}$ On the structural front, the authorities are taking steps to ensure finalization by year-end of two benchmarks that were not observed (completion of an audit of public expenditure management IT systems and of a reform strategy for the civil service pension fund), along with preparation of a strategy to improve PEM - a missed end-March 2008 structural benchmark. The authorities attributed delays to difficulties in mobilizing needed donor support, and stressed that a recent EU decision to provide technical and financial assistance would facilitate progress going forward (MEFP, paragraph 27).

\section{Benin's capacity to repay the Fund is sound and staff supports the authorities'} request for an augmentation of access under the PRGF. The proposed augmentation of access of SDR 9.29 million (15 percent of quota) would increase the total access under the program to 25 percent of quota. It takes into account the country's current indebtedness to the Fund and its excellent debt servicing record (Table 7). During the remainder of the program period (2008-09), the annual average debt service to the Fund would be SDR 0.33 million, or 0.06 percent of export of goods and services and 0.04 percent of government revenue. The request is justified on the basis of a weakening external current account, with the import bill projected to increase by CFAF 65.2 billion in 2008 ( 2.3 percent of 2008 GDP) notably as a result of the shock from rising oil and energy prices. The augmented resources would be made available in one tranche (see Table 1) upon completion of this review.

30. The program will be monitored quarterly, consistent with agreed quantitative and structural performance criteria and benchmarks for specified test dates (MEFP, Tables 1 and 2). On this basis, the fifth PRGF review is to be completed no later than December 2008.

\section{PRSP, OUTREACH, AND OTHER ISSUES}

31. The authorities have articulated ambitious growth objectives in the updated (2007-09) Growth Strategy for Poverty Reduction Paper (GSPRP), which they issued in June 2007. The GSPRP targets an annual real GDP growth of 7-8 percent in the medium term. Like the PRGF-supported program, the GSPRP highlights efforts to enhance economic stability, promote private sector development, and accelerate economic and export

\footnotetext{
${ }^{8}$ The 2008 budget is consistent with the current PRGF arrangement; staff reviewed its outline with the authorities during the third review discussions.
} 
diversification. It assumes improved absorptive capacity and is premised on more external financial assistance to facilitate achievement of the MDGs, and aims to foster regional integration. The authorities concurred that, in addition to increased aid, more rigorous structural and sectoral reforms would be needed to reach the ambitious GSPR growth targets. They also agreed that the GSPR's growth objectives are unlikely to be attained without a substantial improvement in PFM for a better use of fiscal space and acceleration of reforms to improve competitiveness.

32. The first full Annual Progress Report (APR) on implementation of the GSPRP is due out in the second half of 2008. In January 2008 the authorities completed an APR on implementation of the poverty reduction strategy in 2006 and the first quarter of 2007 (the APR and related JSAN are attached). They are finalizing a new APR that assesses progress in implementing the GSPR over the 12-month period through June 2008.

33. Progress toward the MDGs has been slow, and poverty is disappointingly high. In 200637 percent of the population (39 percent in rural areas) lived below the national poverty line of CFAF 82,224, up from 28 percent in 2002. On the other hand, access to basic health and education services has improved.

34. Benin is one of $\mathbf{1 0}$ countries for which increased international support is being planned as part of a United Nations push to facilitate progress toward the MDGs.

Working with UNDP counterparts, staff discussed modalities for implementing the initiative in Benin, including a medium-term budgetary framework that assumes a doubling of budget support to the equivalent of US\$85 per person by 2010, and a consequent scaling-up of progrowth and pro-poor spending. Under the initiative, increased resources would be used to tackle capacity constraints that could hamper effective management of scaled-up budget support. Staff is gauging the macroeconomic implications of anticipated higher external assistance; the assessment is to be completed later in 2008.

35. The quality and availability of statistical data for program monitoring are adequate and improving. The coverage of fiscal data is currently limited to the central government; FAD TA through Afritac-West is helping improve standardized reporting of government financial operations.

36. The mission met with representatives of trade unions, NGOs, and donors to discuss Fund involvement in efforts to boost economic growth and reduce poverty in Benin. Members of civil society and the trade unions underscored the need for enhanced dialogue with government on policy issues; they considered the participatory PRSP process to be a step in the right direction. Donors were concerned about the slow progress in implementing structural reforms. 


\section{Staff ApPraisal}

37. After several years of declining growth, Benin is experiencing a modest economic revival. The challenge will be to build on the progress and raise growth to a rate more consistent with rapid poverty reduction. This will require a more flexible and competitive economy and infrastructure investment. In the short term, Benin will need to weather the strains, including on the balance of payments, of rapid world food and fuel price inflation.

38. Preserving macroeconomic stability is a primary medium-term government objective. The authorities are appropriately consolidating recent gains in revenue mobilization while keeping spending at levels compatible with fiscal viability. They are making determined efforts to make the revenue agencies more efficient, and are scrutinizing spending - especially personnel outlays - to ensure that pro-growth and pro-poor outlays are protected.

39. The authorities have understandably reacted to the food and fuel price shocks which are having a significant impact on vulnerable groups. However, the tax cuts and subsidy measures are likely to be an inefficient and costly way to limit the impact on the poor and should be replaced by more targeted support measures. Staff supports the authorities' plans to move in that direction.

40. The authorities also intend to consolidate recent gains in debt sustainability and to begin addressing Benin's severe absorptive capacity constraints. The MDRI has significantly lowered the debt burden and made space for substantial increases in pro-growth and pro-poor spending, including through additional borrowing. New financing should be obtained on terms that do not jeopardize debt sustainability and planned infrastructure projects routinely be subjected to cost-benefit analysis. Staff encourages the authorities to seek donor support to fill domestic capacity gaps in project design, implementation, and monitoring. It urges timely completion of both the audit of PEM information systems and the reform strategy for improving PEM; and calls for expeditious implementation of recommendations from the latter.

41. Slow progress in reforming the parastatals and cotton sectors is disappointing. Accelerated restructuring of the telecommunications and electricity companies would enable them, along with the port of Cotonou, to enhance competitiveness. In the cotton sector the government's recent decision not to interfere with the awarding of contracts for importation and distribution of fertilizers and other inputs is commendable. It needs to be complemented by long-awaited substantive reforms, especially state disengagement from ginning activities, once the new sector reform strategy is completed in December.

42. Reforms to strengthen the judicial and land tenure systems and facilitate access to credit for more small- and medium-sized enterprises are needed. They would support 
private sector development and allow for diversification of the production and export base, making the economy more resilient to external shocks. There has been continuing progress in preparing feasibility studies and strategies; what is now needed is expeditious implementation of these second-generation and other structural reforms in the cotton and public utilities sectors. The more so because while the real exchange rate appears to be broadly in line with fundamentals, broadly defined competitiveness is far from adequate.

\section{Staff recommends completion of the fourth review of the PRGF arrangement.}

Program performance is broadly on track, and government is working to strengthen revenue mobilization and consolidate spending discipline. However, if the structural reform agenda continues to lag, the lack of progress will compromise the country's growth and poverty reduction prospects. Although implementation remains disappointing to date, the administration has reiterated its readiness to rekindle all areas of the structural reform program. In light of the above considerations, the staff recommends Board approval of the authorities' request for completion of the review and augmentation of the access under the PRGF arrangement. The authorities are encouraged to expedite discussions with donors to secure additional financing to ease the adjustment to high oil and food prices.

\section{Failure of the authorities to rally domestic support for structural reforms is a} key risk to the program along with external factors. High world oil and food prices and the related deterioration in the terms of trade and persistent real currency appreciation are immediate challenges. The authorities concur that greater resilience to shocks can only be built through deepening and expediting the reform agenda.

45. It is proposed that the next Article IV consultation with Benin take place within 24 months, subject to the decision on consultation cycles in program countries. 
Table 1. Benin: Schedule of Disbursements under the PRGF Arrangement, 2005-09 1/

\begin{tabular}{|c|c|c|}
\hline Amount & Disbursement Date & Conditions Necessary For Disbursement 2/ \\
\hline SDR 0.88 million & August 12, 2005 & Executive Board approval of the three-year Arrangement. \\
\hline SDR 0.88 million & December 12, 2006 & $\begin{array}{l}\text { Observance of performance criteria for September } 30,2005 \text {, } \\
\text { completion of the first review under the arrangement. }\end{array}$ \\
\hline SDR 0.88 million & June 15, 2007 & $\begin{array}{l}\text { Observance of performance criteria for December } 31,2006 \text {, } \\
\text { completion of the second review under the arrangement. }\end{array}$ \\
\hline SDR 0.88 million & January 22, 2008 & $\begin{array}{l}\text { Observance of performance criteria for June } 30,2007 \text {, } \\
\text { completion of the third review under the arrangement. }\end{array}$ \\
\hline SDR 10.17 million & June 15, 2008 & $\begin{array}{l}\text { Observance of performance criteria for December } 31,2007 \text {, } \\
\text { completion of the fourth review under the arrangement. }\end{array}$ \\
\hline SDR 0.88 million & December 15, 2008 & $\begin{array}{l}\text { Observance of performance criteria for June } 30,2008 \text {, } \\
\text { completion of the fifth review under the arrangement }\end{array}$ \\
\hline SDR 0.91 million & June 15, 2009 & $\begin{array}{l}\text { Observance of performance criteria for december } 31,2009 \text {, } \\
\text { completion of the six review under the arrangement. }\end{array}$ \\
\hline
\end{tabular}

Source: International Monetary Fund.

1/ Assuming access equivalent to 10 percent of quota, or SDR 6.19 million.

2/ Other than the generally applicable conditions under the PRGF arrangement, including the performance clause on the exchange and trade system. 
Table 2. Benin: Selected Economic and Financial Indicators, 2006-13

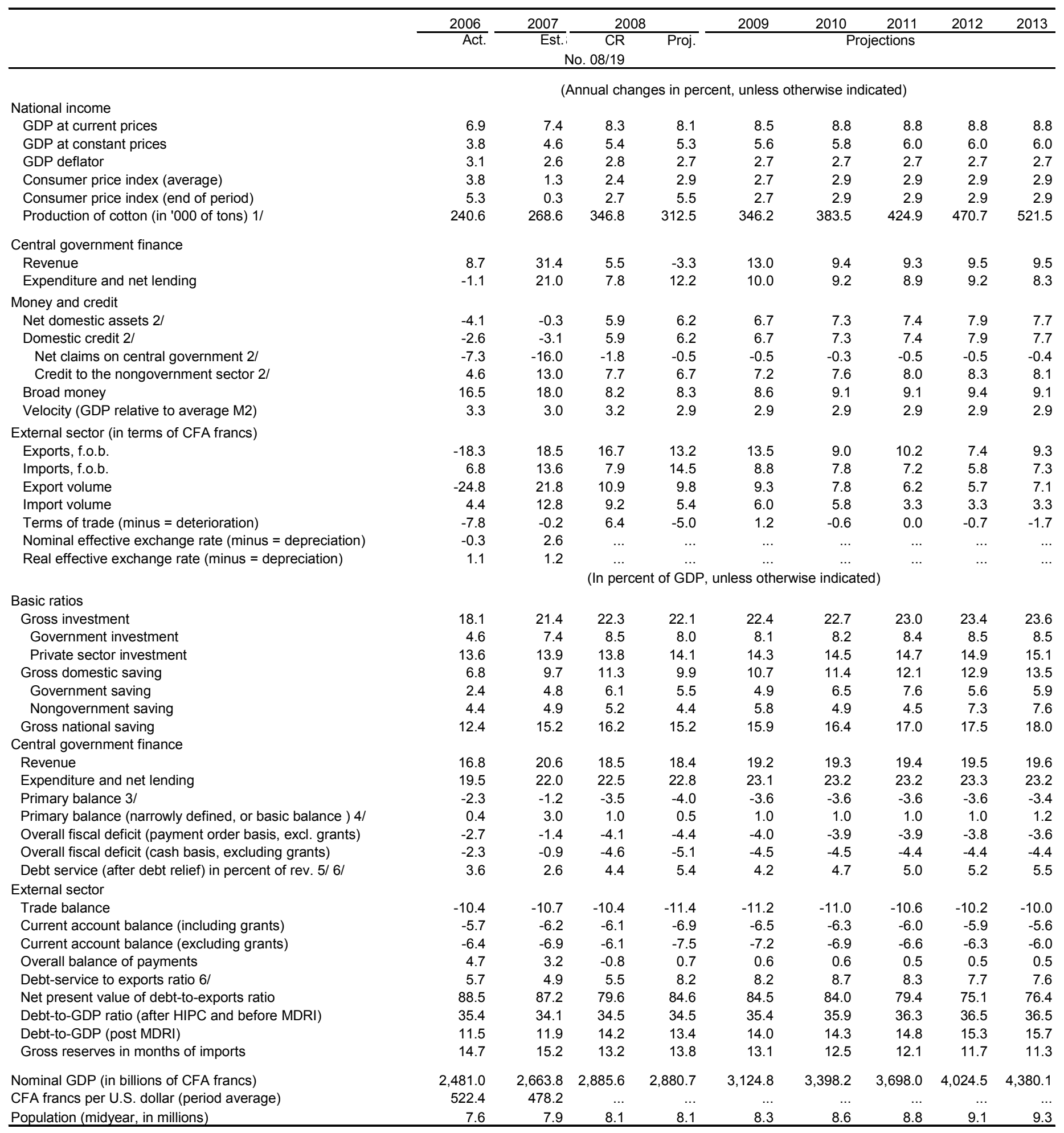

Sources: Beninese authorities; and IMF staff estimates and projections.

$1 /$ Cotton production for $\mathrm{T}-1 / \mathrm{T}$ season. Production of cotton seed in crop year T-1/T affects agricultural production in year

$\mathrm{T}-1$, while industry, services, and exports of ginned cotton in year T.

2/ In percent of broad money at the beginning of the period.

$3 /$ Total revenue minus all expenditure, excluding interest due.

4/ Total revenue minus all expenditure, excluding foreign-financed capital expenditure and interest due.

$5 /$ Interest payment only.

6/ The 2006 projections incorporate the MDRI resources for the IMF, IDA and AfDF in stock operations. 
29

Table 3 . Benin: Consolidated Central Government Operations, 2006-13

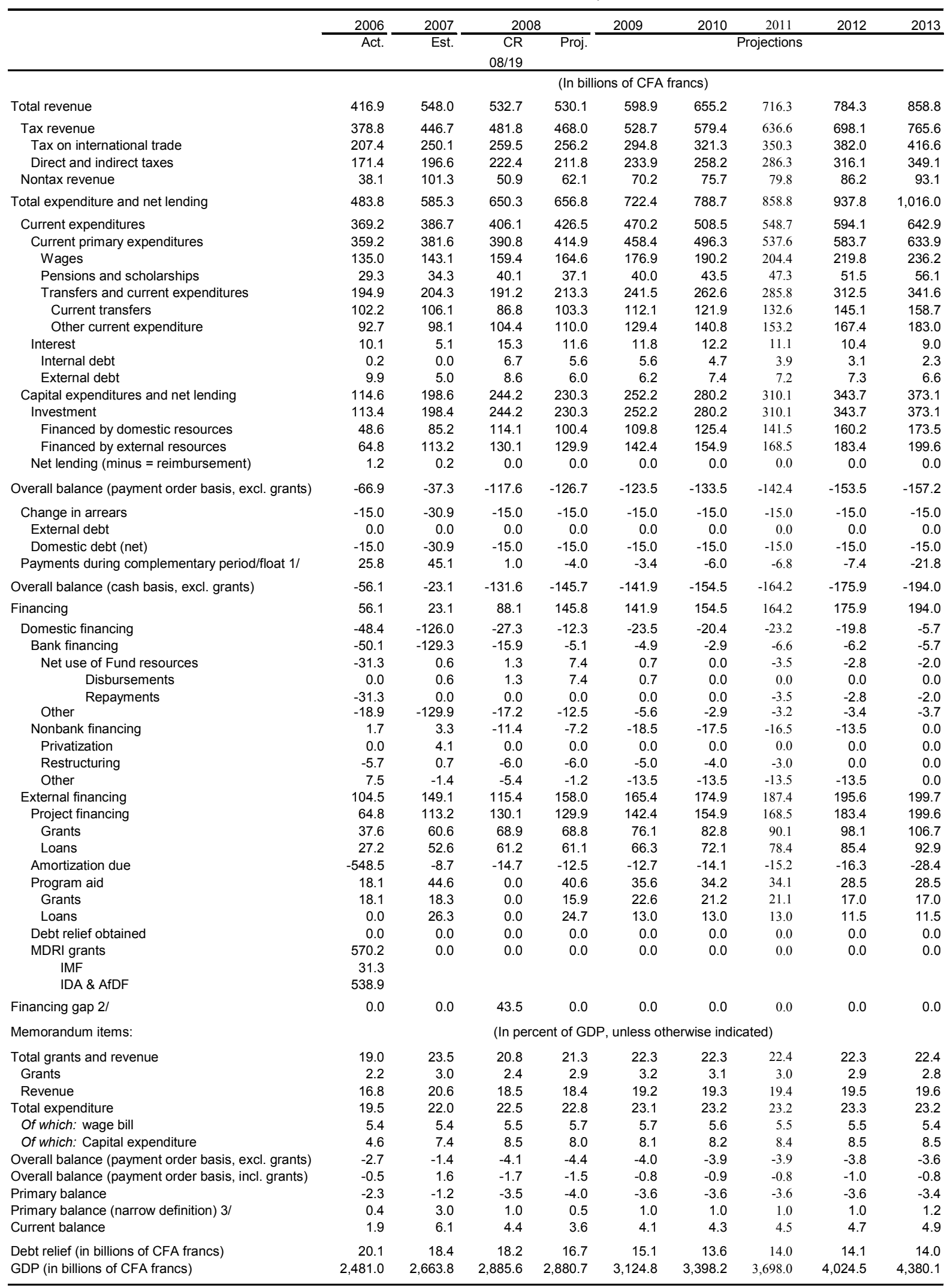

Sources: Beninese authorities; and IMF staff estimates and projections.

1/ Payment orders curried over to the following fiscal year

2/ For 2008, adequate financing has been identified from bilateral and multilateral partners.

$3 /$ Total revenue minus total expenditure, excluding investment financed from abroad, interest payments and net lending. 
Table 4. Benin: Consolidated Central Government Operations, 2006-13 (Percent of GDP)

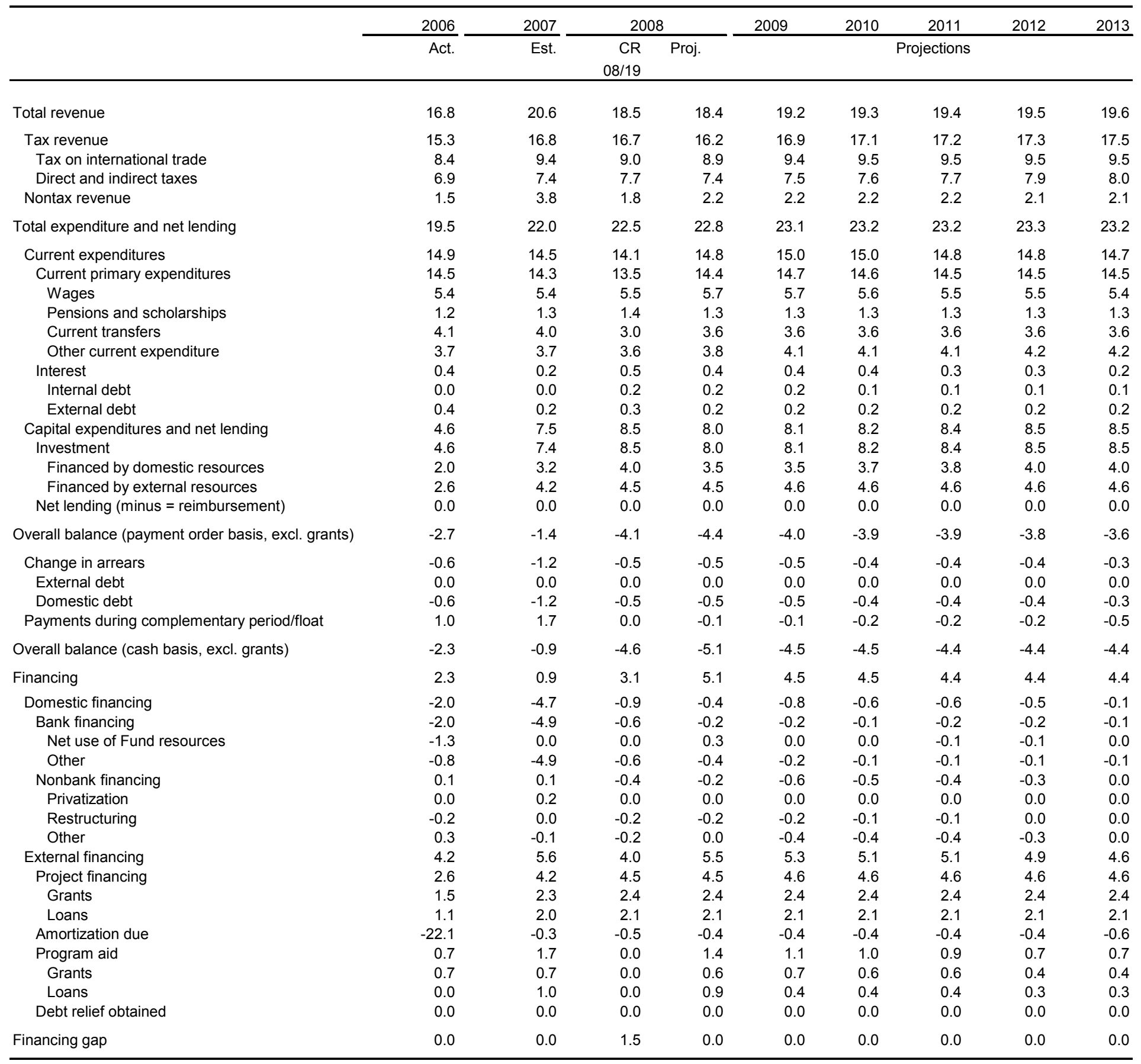

Sources: Beninese authorities; and IMF staff estimates and projections. 
Table 5. Benin: Central Government Operations, Quarterly , 2007-09

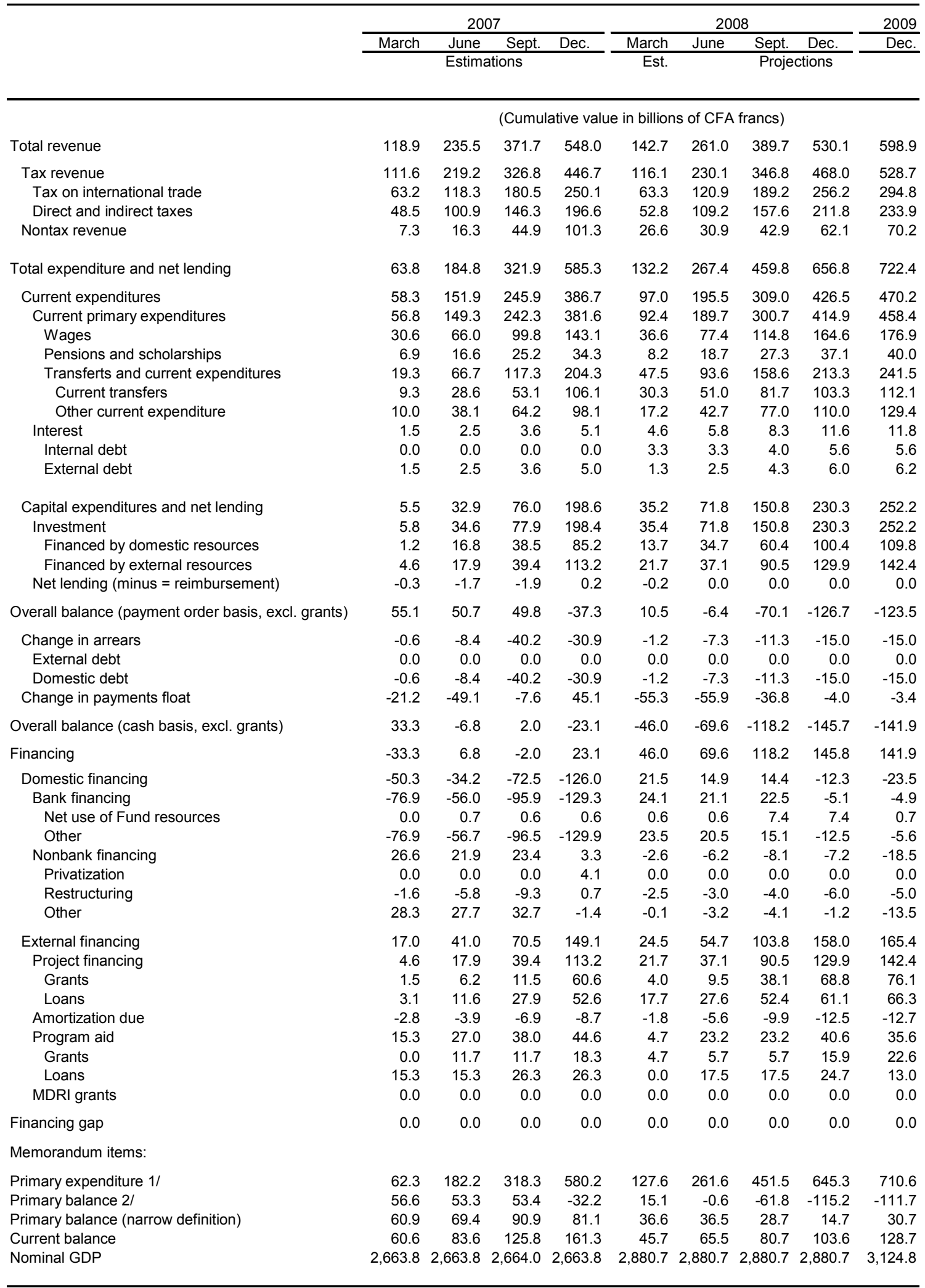

Sources: Beninese authorities; and IMF staff estimates and projections.

$1 /$ Total expenditure minus interest obligations.

2/ Total revenue minus primary expenditure. 
Table 6. Benin: Balance of Payments, 2006-13

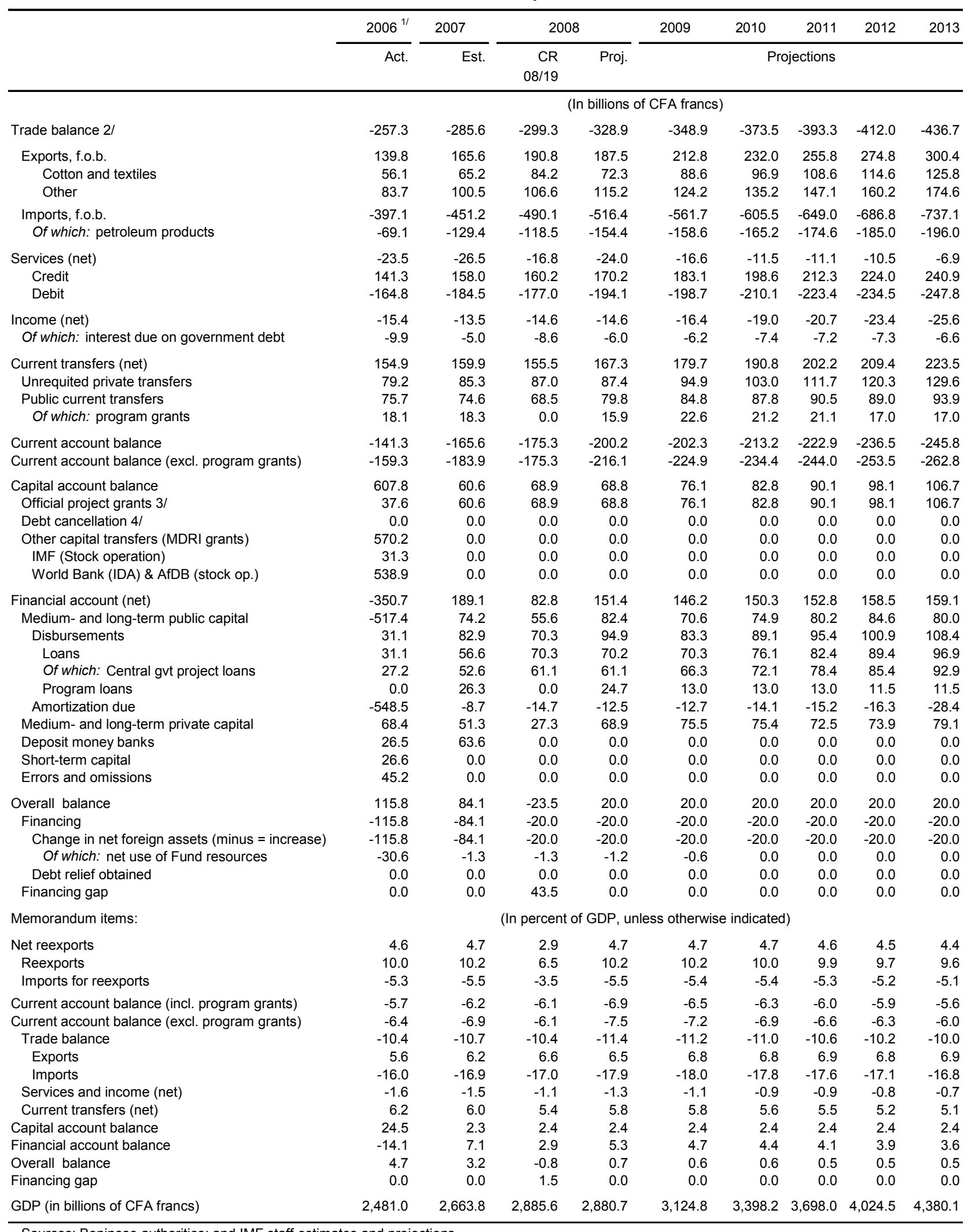

Sources: Beninese authorities; and IMF staff estimates and projections.

$1 /$ Incorporating debt relief under the MDRI (IMF, IDA and AfDF) in stock operations

2/ Excluding reexports and imports for reexports, net balance of which is allocated between services and public transfers.

3/ Official capital grants from the United States (MCA) of the amount of US \$ 307 millions will be disbursed over the period $2006-2011$.

4/ The entry in 2003 is for the stock-of-debt operation at the HIPC completion point. 


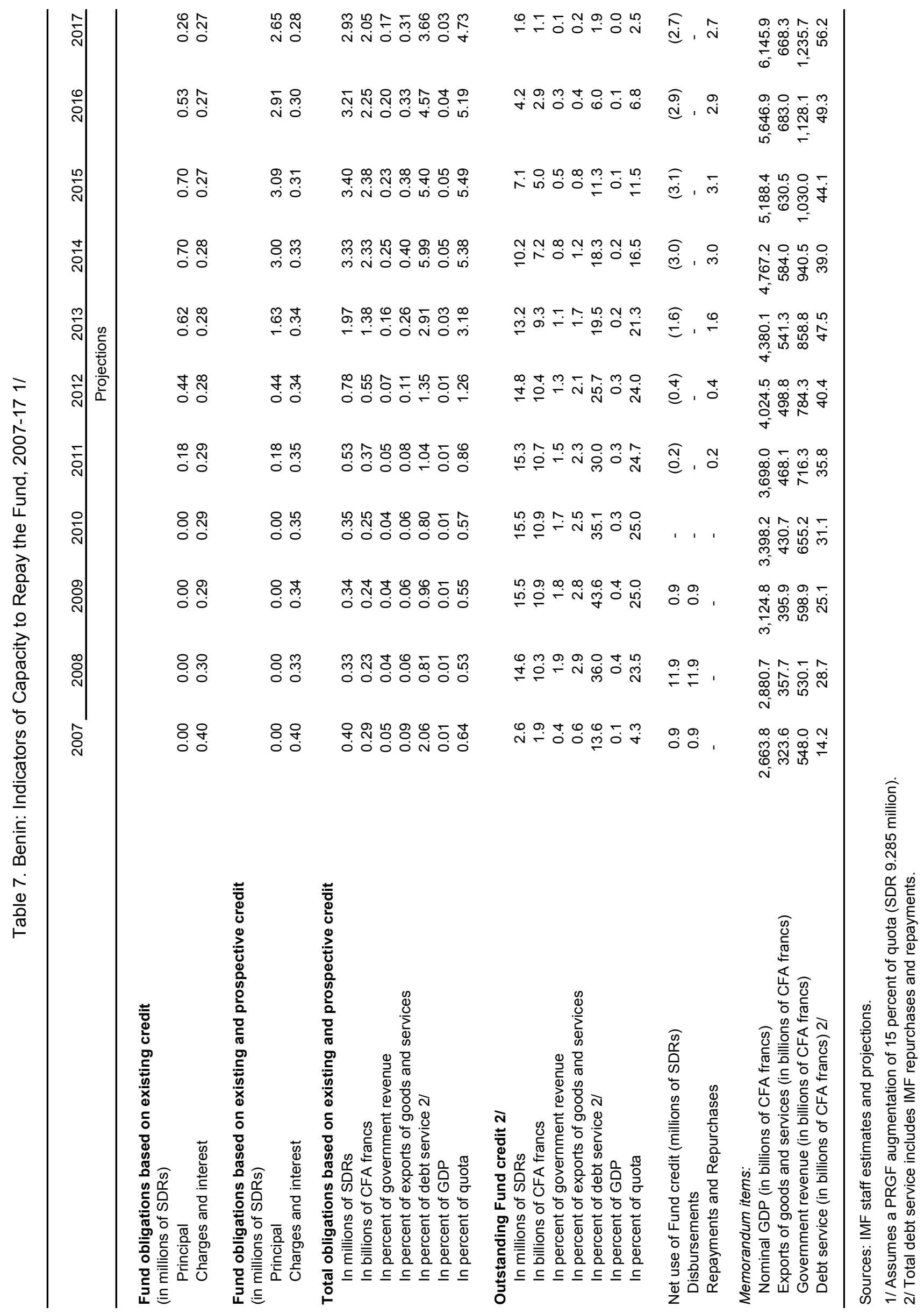




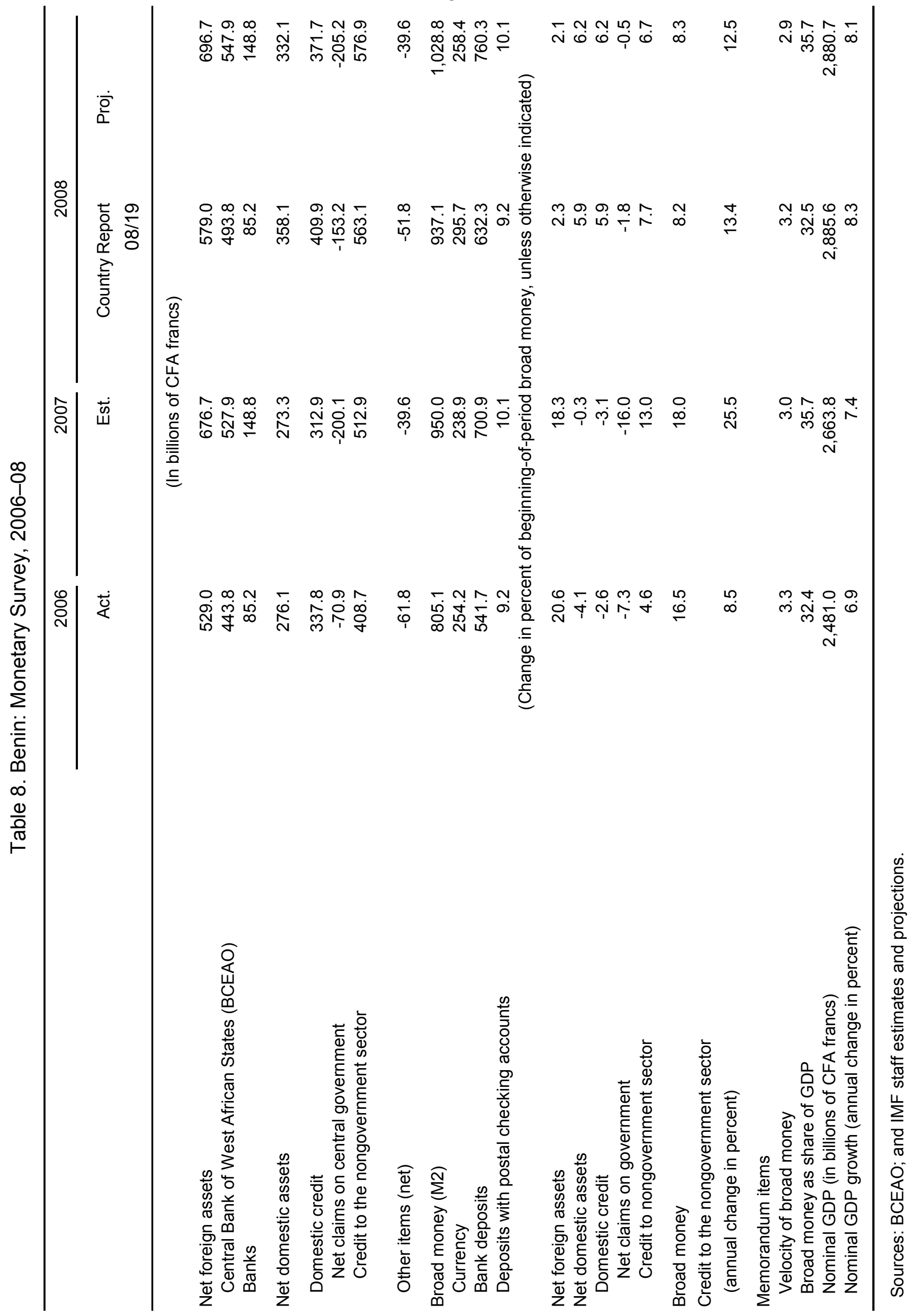




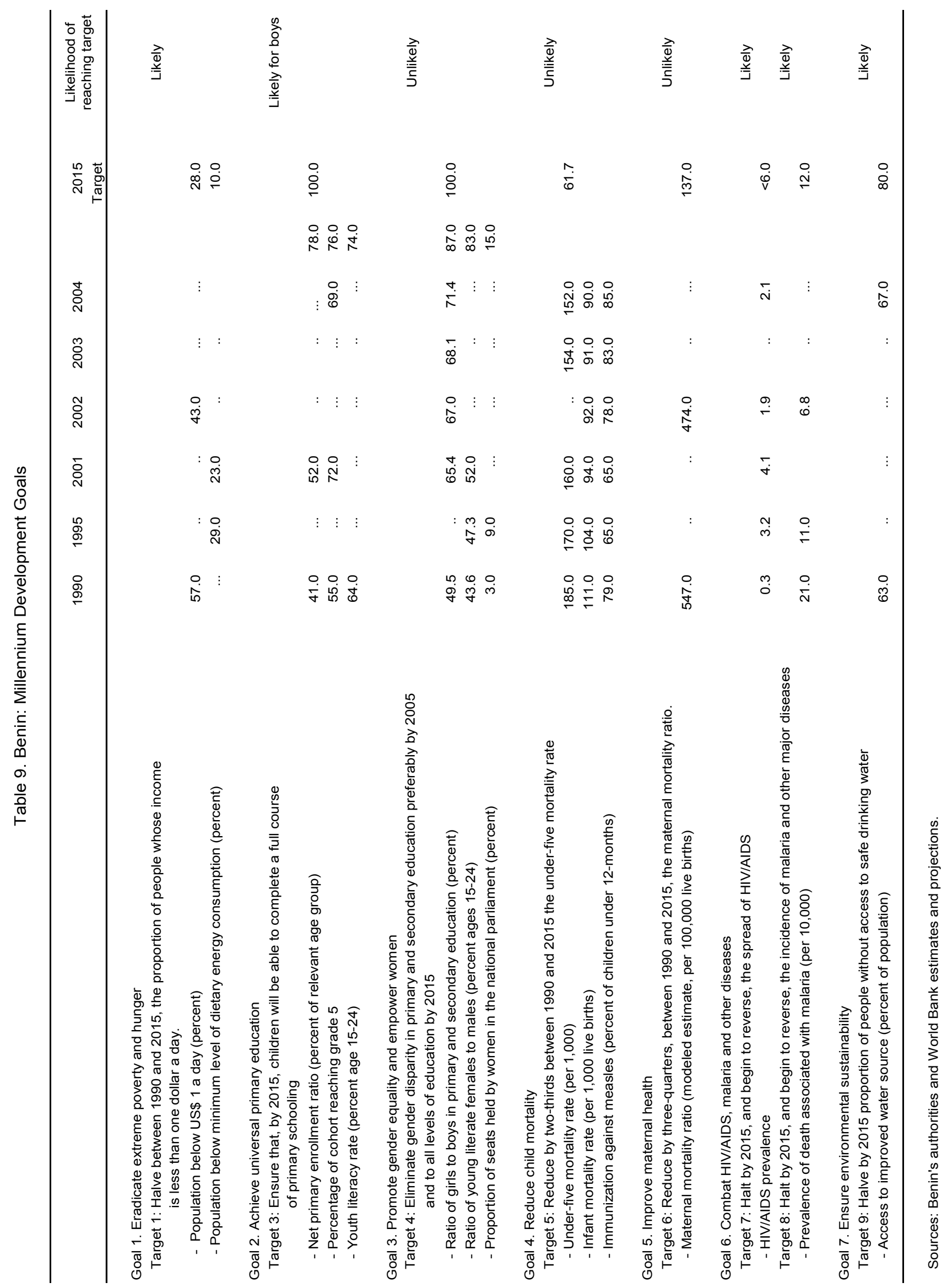




\section{APPENDIX I-LETTER OF INTENT}

REPUBLIC OF BENIN

MINISTRY OF ECONOMY AND FINANCE

Cotonou, May 30, 2008

\section{THE MINISTER}

To:

Dominique Strauss-Kahn

Managing Director

International Monetary Fund

Washington, DC 20431

\section{Dear Sir:}

1. A Fund staff mission visited Cotonou, Benin, during March 3-17, 2008 to conduct discussions under the fourth review of the reform program supported by the arrangement under the Poverty Reduction and Growth Facility (PRGF). The mission also engaged in consultations under Article IV of the IMF's Articles of Agreement for 2008. Upon completion of the mission's discussions with the government, it was determined that all the quantitative performance criteria and benchmarks set for end-September and end-December 2007 had been observed. With respect to structural reforms, two of the four structural benchmarks under the program - namely, the audit of IT systems for public expenditure management and preparation of the reform strategy for national pension fund-were not met. However, the government has taken appropriate steps to ensure the successful completion of these measures before year end.

2. The mission noted that the rebound in growth observed since 2006 gathered momentum in 2007, with real GDP growth reaching 4.6 percent, as against 3.8 percent in 2006. This was driven by the service sector, in particular transport and communications, and commerce, reflecting a substantial upturn in activity at the Port of Cotonou. Growth has also been enhanced by relatively favorable performance in agriculture - including cotton production - although activity in the cotton sector has been weaker than anticipated. The government intends to build upon and consolidate the results achieved to date. Accordingly, it is committed to pursuing implementation of its structural reform program to improve economic competitiveness and put the economy on a path of strong and sustainable growth with the aim of addressing the challenges of poverty reduction more effectively. 
3. On December 8, 2007, the Government introduced fiscal measures to address rising food and oil prices. The tax cuts and subsidies entail some revenue loss and include limited transfers to public utilities to contain anticipated energy cost increases. Beyond contributions from other donors, the government is requesting additional resources from the Fund (0.2 percent of GDP) to cover the resulting balance of payments financing needs.

4. The government wishes to continue benefiting from IMF technical and financial assistance under the PRGF-supported program, and is therefore requesting the conclusion of the fourth review and disbursement of related financial assistance from the Fund. It consents to the publication of both the staff report and the memorandum on economic and financial policies pertaining to the discussions under the fourth review of the program.

Very truly yours,

$$
\text { /s/ }
$$

Soulé Mana Lawani 


\section{APPENDiX I. ATtaChMENT I-Memorandum on Economic and Financial Policies for $2007 / 08$}

\section{INTRODUCTION}

1. The economic recovery that started in $\mathbf{2 0 0 6}$ continued and was consolidated in 2007. However, real GDP growth remained below initial projections and under the minimum required for achieving the Millennium Development Goals (MDGs). Based on the available data, economic growth in 2007 is estimated at 4.6 percent, compared with 3.8 percent in 2006. This resulted from picked up activity in the trade, transportation, and agriculture sectors. The energy crisis dampened the economic expansion, especially in the secondary sector.

2. In 2007, domestic price increases decelerated further, contributing to the stabilization of the real effective exchange rate. Despite strong pressure in the latter months of the year, moderate food price increases during most of the period - as a result of a good agricultural season, but also reflecting in part the impact (probably limited) of price control measures introduced in November-helped lower average inflation to 1.3 percent, compared with 3.8 percent in 2006. Thus, the inflation differential between Benin and its trading partners improved further, helping to stabilize the real effective exchange rate despite the nominal appreciation of the CFA franc against the dollar.

3. The overall external position strengthened, driven by improvements in the financial accounts of the balance of payments. The deterioration in the external current account was more pronounced than expected, with the deficit (excluding official grants) reaching 6.9 percent of GDP, from 6.4 in 2006. Imports increased sharply, especially those of petroleum products in a context of much higher world prices and increased use of generators by households and businesses faced with limited electricity supply from the National Electricity Company (SBEE). On the other hand, the financial account of the balance of payments improved as a result of higher official capital flows in the form of concessional loans, but also sustained by rising foreign assets for commercial banks; the latter reflecting, inter alia, higher off-budget donor support. Consequently, the overall balance of payments recorded a surplus of 3.2 percent of GDP, which helped maintain official reserves at a level equivalent to some 15 months of imports.

\section{In 2007, continued fiscal consolidation in a context of limited absorption} capacity led to a further strengthening of the basic fiscal balance. More efforts were made to enhance domestic revenue collection, while spending was broadly contained within program limits despite overruns in various transfer items. Total revenue increased to the equivalent to 20.6 percent of GDP, compared with 16.8 percent in 2006 and 19 percent of GDP under the program. At the same time, total basic outlays were limited to 17.6 percent of 
GDP (compared with a targeted 18 percent under the program), reflecting lower-thanprogrammed capital expenditure - as the authorities facing inadequate capacity in project design, implementation, and monitoring, remained confronted with difficulties (institutional and administrative) in the management of the investment budget. Consequently, the surplus on the basic fiscal balance increased to the equivalent of 3 percent of GDP $(0.4$ percent in 2006), compared with a target of 1 percent under the program.

5. Customs revenue performance exceeded program objectives. Receipts totaled CFAF 250.1 billion or 9.4 percent of GDP, compared with 8.4 percent in 2006 . The improvement was attributable to a strengthening of governance, intensification of anti-fraud activities at land borders, and improved valuation of imports. Customs administration also endeavored to simplify imports clearance procedures and formalities, and enhanced the monitoring of exemptions. The improved customs revenue performance was also underpinned by a substantial increase in the value of imports.

\section{Domestic direct and indirect tax revenue also rose considerably, reaching} CFAF 197 billion or 7.4 percent of GDP, from 6.9 percent in 2006. This was, however, 0.2-percentage point below target; but reflecting continued efforts to improve tax administration, with a focus on the Large Taxpayer Unit (DGE) and the Medium-Sized Enterprise Tax Centers (CIMEs). These units' activities are now squarely centered on monitoring the fiscal obligations of the largest businesses, representing over 80 percent of the tax base. On the other hand, as part of the effort to standardize management of the tax on industrial and commercial profits (BIC), big enterprises under DGE purview are no longer subject to the tax withholding system under which advance payments on profit taxes (AIB) were collected at customs. This is helping reduce the large tax credits accumulated in the last years, gradually easing related tax management and collection problems. The relatively high VAT yield resulted from intensified controls in monitoring the tax base and securing collection.

\section{In 2007, nontax revenue exceeded by far the program target and significantly} contributed to the increase in government receipts. The gains stemmed mostly from oneoff license fees from mobile telephone companies, in an amount totaling CFAF 61 billion (2.3 percent of GDP).

\section{Government expenditure was broadly within program limits, reaching} CFAF 585.3 billion or 22 percent of GDP, compared with a projected 22.6 percent under the program. Current spending was marked by sizable overruns in various transfer items, reflecting government support to the microfinance and crisis-afflicted energy sectors. Other current outlays, including the wage bill, were contained within program limits. Domestically financed capital expenditure was one percentage point of GDP below target, corresponding to an implementation rate of 69 percent (57 percent in 2006). 
9. The overall fiscal deficit (commitment basis, excluding grants) was reduced to 1.4 percent of GDP (compared with the programmed 3.7 percent of GDP), settling at CFAF 69.4 billion. The bulk of budgetary support, in the form of program assistance, was granted by: (i) the World Bank: CFAF 15.3 billion; (ii) the European Union:

CFAF 11.7 billion; (iii) the African Development Bank: CFAF 11 billion; and (iv) The Netherlands: CFAF 6.6 billion.

10. Monetary developments were dominated by a sharp increase in money supply, resulting from a buildup of external reserves and a rapid expansion of credit to the economy. Net credit to the government further declined, with a considerable increase in Treasury deposits reflecting the improvement of the budgetary situation and expansion of government's overall resources envelope. By and large, developments in the monetary sector were in line with those in both the real sector and balance of payments. The central bank maintained the required reserve ratio at 15 percent.

\section{Program implementation}

11. All quantitative performance criteria and benchmarks for end-December 2007 were observed. In the structural area, only two of four benchmarks were observed. In particular, although the single taxpayer identification number system was introduced and the study on the effectiveness of customs was completed, the audit of public expenditure management information systems and the reform strategy for the civil service pension fund are still pending.

\section{Economic and Financial Policies in 2008}

\section{A. Macroeconomic Framework}

12. The government is determined to consolidate the economic recovery under way and to put the economy on a path of strong and sustainable growth. To that end, it will take steps to anchor recent gains in macroeconomic stabilization, strengthen economic and social infrastructure, and expedite the structural reform agenda. In the circumstances, the medium-term economic outlook remains positive, with real GDP growth projected at 5.3 percent in 2008, and inflation contained within the limits of the WAEMU convergence criterion. Domestically financed public capital outlays would amount to 3.5 percent of GDP in 2008, one percentage-point above the average for the past two years.

13. The government remains committed to market-based price policies. In light of current price increases for key commodities such as rice, wheat, cement, and petroleum products, the government introduced selected price control measures in the last quarter 
of 2007. In particular, it suspended or reduced customs duty rates for concerned products; and made subsidy transfers to the state-owned electricity (SBEE) and petroleum distribution (SONACOP) companies in a bid to keep in check increases in retail energy product prices. The government intends to lift these measures as soon as possible. To encourage domestic production and supply of essential goods, in particular for food products, the government is committed to ensuring that food prices do reflect production costs over the medium to long term. Consequently, going forward, should current price pressures persist, the government intends to make use of consumption subsidies to targeted social groups instead. To that effect, it will establish social safety nets with technical assistance from development partners, as needed.

14. Serious risks weigh on the economy in 2008. In the short run, the risks relate mostly to the impact of an appreciating Euro-pegged CFA franc, rising prices of petroleum and other key consumer products, and heightened wage demands from trade unions. Over the medium term, delays in implementing structural reforms in the cotton, electricity, and telecommunications sectors would also affect macroeconomic developments. These risks are, however, offset, at least in part, by the positive effects of trade with the oil-based Nigerian economy.

\section{B. Fiscal Policy}

\section{In 2008, fiscal policy is aimed at preserving recent gains in macroeconomic} stabilization, helping to improve absorption capacity, and supporting the economic recovery. To that end, total government revenue and expenditure would reach 18.4 percent of GDP and 22.8 percent of GDP, respectively. The surplus on the basic fiscal balance would be equivalent to $1 / 2$ percent of GDP, meeting the WAEMU target with some margin. It is anticipated that the overall fiscal deficit (commitment basis and excluding grants) would be contained at a level equivalent to 4.4 percent of GDP. Fiscal consolidation would thus be pursued, and spending on infrastructure and poverty reduction programs would further increase, as absorption capacity is enhanced.

\section{Government revenue is expected to total CFAF 530.1 billion or 18.4 percent of} GDP, taking account of 1 percent of GDP in losses from fiscal measures to address rising food and oil prices. ${ }^{1}$ In addition to the impact of increased import volumes on customs revenue, the performance is attributable to several recently introduced measures to broaden the tax base, including: (i) establishment of a single taxpayer identification number system, (ii) strengthening of tax and customs control administration units, (iii) expansion of CIMEs, (iv) enhanced monitoring of VAT returns at the Large Taxpayer Unit, (v) more

\footnotetext{
${ }^{1}$ Elimination of customs tariffs and/or reduction of customs fees for imports of key food items and for petroleum products.
} 
rigorous post-customs clearance monitoring of exemptions, and (vi) extension of ASYCUDA++ to several provincial customs posts.

\section{Spending is projected at CFAF 656.8 billion in 2008, corresponding to an} increase of 12.2 percent. This would help meet the annual cost of the economic and social infrastructure rehabilitation program that started in 2007; it also takes account the wage increase granted to public sector teachers. Overall, the wage bill would increase to the equivalent of 5.7 percent of GDP to meet the urgent personnel needs of the key sectors of education and health, agriculture, and the revenue agencies. In the medium term, the government plans to maintain the wage bill at levels consistent with the ceiling under the program, and to contain wage outlays at 5.5 percent of GDP. Capital expenditure is projected to total CFAF 230.3 billion or about 8 percent of GDP. The government will continue settling the outstanding wage debt to civil servants, including through securitization as needed.

\section{The overall fiscal deficit (cash basis, excluding grants) is projected at 5.1 percent} of GDP. It is to be financed mainly with budgetary support from the European Union and other bilateral and multilateral partners, including the World Bank, the African Development Bank.

\section{The government continues ongoing efforts to preserve fiscal discipline and} improve public expenditure management. To enhance the quality of spending, the government remains committed to ensuring the strict observance of established expenditure execution procedures, and would resort to exceptional spending channels only sparingly. In particular, the use of Treasury payment orders (ordres de paiement Trésor) will continue to be limited to a strict minimum. The government is also taking steps to enhance its capacity to absorb mobilized resources. To this end, it is increasing the personnel and material means at the disposal of key spending ministries, with a special emphasis on units responsible for managing the investment budget. In this vein, the programming and forecasting directorates of the line ministries will be reinforced, and efforts are under way to improve the effectiveness of the National Procurement Regulatory Committee (CNRMP) and the National Public Procurement Directorate (DNMP), as well as the performance of procurement units (CPMPs) in the technical ministries.

\section{Money and Credit}

20. Monetary policy conducted at the regional level by the BCEAO will continue to seek preservation of price stability, a strengthening of the zone's external position, and maintenance of international reserves at an adequate level. Broad money is expected to grow by 8.3 percent in 2008, in line with the increase in nominal GDP, with net foreign assets and credit to the private sector increasing by 2.1 percent and 6.7 percent of beginningof-period money supply, respectively. Continuing a recent trend, net bank credit to the 
government is projected to decline slightly, as public finance improves further, facilitating an expansion of credit to the private sector.

21. In setting the required reserve ratio, the authorities will continue to take account of developments on the inflation and short-term credit fronts. Given that credit growth and inflation are expected to be relatively moderate in 2008, a lowering of the required reserve ratio from the current high of 15 percent could be envisaged, especially in the absence of risks of capital flight, and assuming no significant deterioration in the quality of commercial bank portfolio.

\section{Despite a surge in activity during 2006-07, the banking sector remains}

vulnerable. Deposits increased by nearly 30 percent in 2007 and bank credit rose by 26 percent. However, three of the country's twelve banks accounted for more than 60 percent of bank deposits in 2006-07; and four institutions bore 80 percent of nonperforming loans (NPLs) in 2007. These increased by 8 percent in 2007, accounting for 9 percent of total bank loans. In the circumstances, the low level of bank capitalization has limited commercial banks' ability to observe certain prudential ratios. In December 2007, eight of Benin's twelve banks did not observe the minimum capital adequacy requirement, compared with six (out of twelve) in December 2006; but the decision to raise the required minimum capital is expected to correct this weakness in 2008. None of the twelve banks observed the portfolio structure ratio. Concerned about this situation, the government is carefully monitoring implementation of the decision to adjust the minimum capital requirement; it is also closely working with the National Assembly to ensure an early ratification of the regional agreement enhancing the supervisory powers of the WAEMU Banking Commission.

\section{Recent bank supervision missions by the Banking Commission have highlighted} a number of remedial measures to address key weaknesses in the banking system. Improvements are especially needed in the areas of corporate governance, information systems, risk management, downgrading of loans, and loss accounting.

\section{Balance of Payments and External Debt}

24. In 2008, the external current account deficit, excluding grants, is expected to widen to 7.5 percent of GDP, from 6.9 percent in 2007 . For the most part, this would reflect the impact of higher oil and food prices, notwithstanding the relatively good performance of cotton exports, and a revival of net re-exports, the upshot of reforms under way at the port of Cotonou. Imports of intermediate and capital goods would also somewhat go up in the face of higher public investment demand and stronger private sector activity in several areas. As a result of private financial flows related to these developments, but also reflecting anticipated program and project grants and loans, the balance of payments is 
expected to show a slight surplus in 2008, which would permit Benin to contribute to programmed build-up in BCEAO reserves.

25. The government remains committed to pursuing a prudent debt policy, which is key to ensuring preservation of external debt sustainability. It intends to put the proceeds of loans contracted to good use, in support of its growth objectives and with a view to enhancing availability of basic social services in the country.

\section{E. Structural Policies}

\section{Public expenditure management}

26. The government is making determined efforts to improve public expenditure management. After being granted debt relief under both the HIPC Initiative and MDRI, Benin is making increasing gains in domestic revenue mobilization. The government is determined to ensure adequate use of the fiscal space thus created. To this end, it intends to expedite efforts to modernize public expenditure management systems, with a view to enhancing their effectiveness.

27. Improving budget management remains a priority. The actions envisaged in this area include, in particular, the preparation of an audit of the automated public expenditure management systems (SIGFIP, ASTER, and WMONEY). The audit was initially scheduled to be completed before end-December 2007 (a structural benchmark in the program), a deadline missed because of delays in mobilizing needed external financing. With support from the European Union now secured, the government has issued an invitation to bid for the recruitment of a consultant of international repute that is to carry out the audit by endDecember 2008 (reset structural benchmark). Implementation of recommendations would make monitoring of expenditure execution more reliable. In the same context, the government is determined to expedite preparation of two delayed strategies to : (i) address the deteriorating financial situation of the civil service pension fund, an end-December 2007 structural benchmark; and (ii) improve public expenditure management - a structural benchmark for end March 2008. The two strategies are now to be finalized by endDecember 2008 (reset structural benchmarks). Steps have been taken to ensure that Budget and Treasury officials assume more fully responsibility for monitoring implementation of these program benchmarks.

\section{The government has initiated actions to improve management of the investment}

budget. It is determined to ensure that capital outlays do Benin's growth objectives and, to that end, is working to address capacity constraints that have prevented implementation of more ambitious public investment programs. This is key to the success of the government's economic and social infrastructure rehabilitation program. In this context, the human and 
material resources at the disposal of public investment management units, including in the area of procurement, are being increased. At the same time, the government is endeavoring to enhance its project design, implementation, and monitoring capacity; and has taken steps to further strengthen the monitoring of investment projects in the technical ministries. In this context, bi-monthly project execution reports are to be submitted to the Council of Ministers and posted on the website of the Office of the President of the Republic.

\section{Reforms of the cotton, energy, and telecommunications sectors}

29. The government is preparing a comprehensive strategy for reform of the cotton sector. Despite government willingness to secure enhanced private sector involvement in cotton ginning activities, state disengagement from SONAPRA was not achieved in 2007, owing in part to limited private sector interest. Drawing the lessons, the government has initiated preparations for an in-depth strategy that should reassert the government's plan to disengage from industrial and commercial activities, and more generally make reform recommendations likely to help enhance the efficiency and competitiveness of the cotton sector.

\section{The new cotton sector reform strategy is expected to be completed by end-}

December 2008. The government intends to develop its strategic pillars in the second quarter of 2008, and to conduct participatory consultations with key stakeholder groups in the third quarter of the year with a view to securing broad-based ownership of proposed efficiencyenhancing reforms. Following adoption of the reform package at end-December 2008, agreed reform measures would be implemented over a 2-3 year period.

31. Reform of the energy sector will continue. It is critical for nurturing competitiveness. The initial deadline for effecting state divestiture by January 2009 had not fully taken into account the actual operating conditions at the national electric power company (SBEE). Recent investigations have uncovered numerous administrative, financial, accounting, technical, and commercial irregularities in company management. As result, restructuring had become essential for ensuring successful state divestiture; and implementation of a two-year SBEE restructuring program has been under way since January 2008.

\section{The government plans to conduct an overall assessment of the SBEE} restructuring program in December 2009 with a view to defining content and timing of state divestiture. Special emphasis is to be placed on capacity building needs to provide the company with competent technical and managerial staff. The government is counting on support from the Bretton Woods institutions in carrying out agreed reforms for the sector. 


\section{Power production and transport will be the subject of a national strategy to be} developed in the coming months. The production and distributing of electric power require heavy investments. The sector will be the subject of a national strategy that is to be developed taking account of the findings of ongoing work by a subregional committee tasked by the WAEMU heads of state with finding solutions to the region's severe energy crisis.

\section{Opening up the equity capital of the national telecommunications company}

(Bénin Télécoms SA) is a government priority. The telecommunications sector has been reorganized, in particular with respect to the GSM mobile telephone system. A transitional regulatory authority has been set up and is effectively exercising its oversight prerogatives, especially in the area of international communications. As regards Bénin Télécoms SA, implementation of a restructuring program endorsed in December 2006 by the company's main creditors and approved by the government, is under way. It is to be completed in January 2009. A strategy note on state disengagement is being prepared, and is expected to be submitted to government approval in the second quarter of 2008. In view of extensive preparatory work following government adoption of the strategy, the call for bids from potential private sector investors could be issued in the second half of 2009 .

\section{Port sector reform}


35. With support from MCA-Benin, the government is continuing implementation of measures to enhance the competitiveness of the Autonomous Port of Cotonou. Key strategic areas of port reform include measures to enhance private sector involvement in management, and to improve customs effectiveness in mobilizing revenue and facilitating trade. The government completed on March 20, 2008, a review of bids pertaining to the recruitment of a port expert that is to help modernize port operations. As anticipated under the program, the expert is to become operational by end-June 2008. Also, the government has completed a study on the efficiency of Benin's customs operations. The study stresses the need for a one-stop shop at the port, which the government intends to set up, complete with a consolidated electronic billing system (BFU), by end-September 2008. These actions would help increase the fluidity of foreign trade and improve customs revenue collection.

\section{F. Growth and Poverty Reduction Strategy Paper (GPRSP)}

36. The government has started preparations for the 2007 annual progress report (APR) on the implementation of the 2007-09 PRSP. The report's terms of reference have been drawn up, and the government is making every effort to take account of the relevant comments from development partners. It intends to have the APR finalized by endJune 2008.

\section{Monitoring of Program Implementation}

37. Program monitoring will be effected on the basis of quarterly quantitative and structural performance criteria and benchmarks (Tables 1 and 2). The authorities will report the data necessary for program monitoring to the IMF, in accordance with relevant requirements under the Technical Memorandum of Understanding (TMU). Over the program period, the authorities will neither introduce restrictions on payments and transfers on current international transactions, nor tighten any such restrictions, without first consulting the Fund; introduce or modify multiple currency practices; conclude bilateral payments agreements not compatible with the provisions of Article VIII of the IMF's Articles of Agreement; or introduce restrictions on imports for balance of payments purposes.

38. The fifth and sixth reviews under the PRGF arrangement will take place by endNovember 2008 and end-April 2009, respectively. 


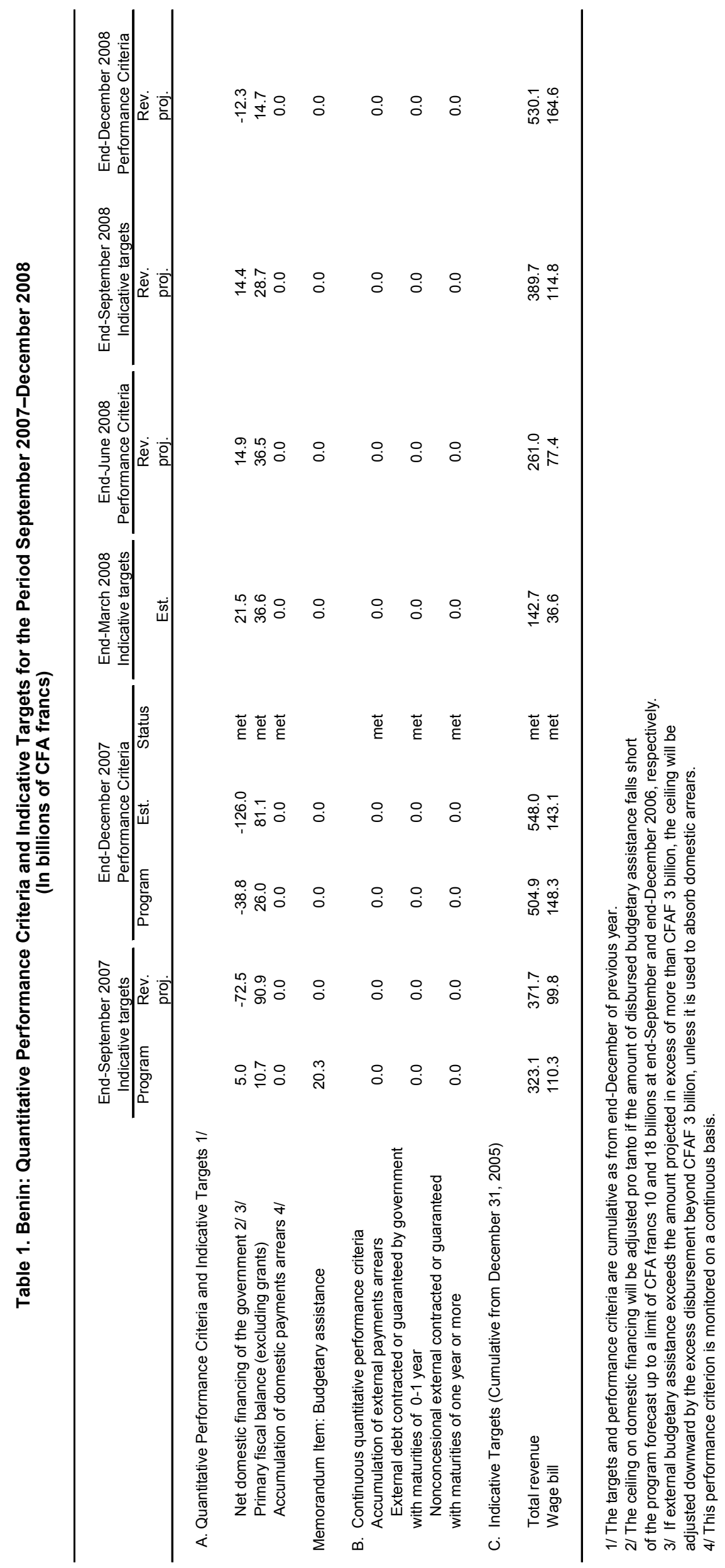




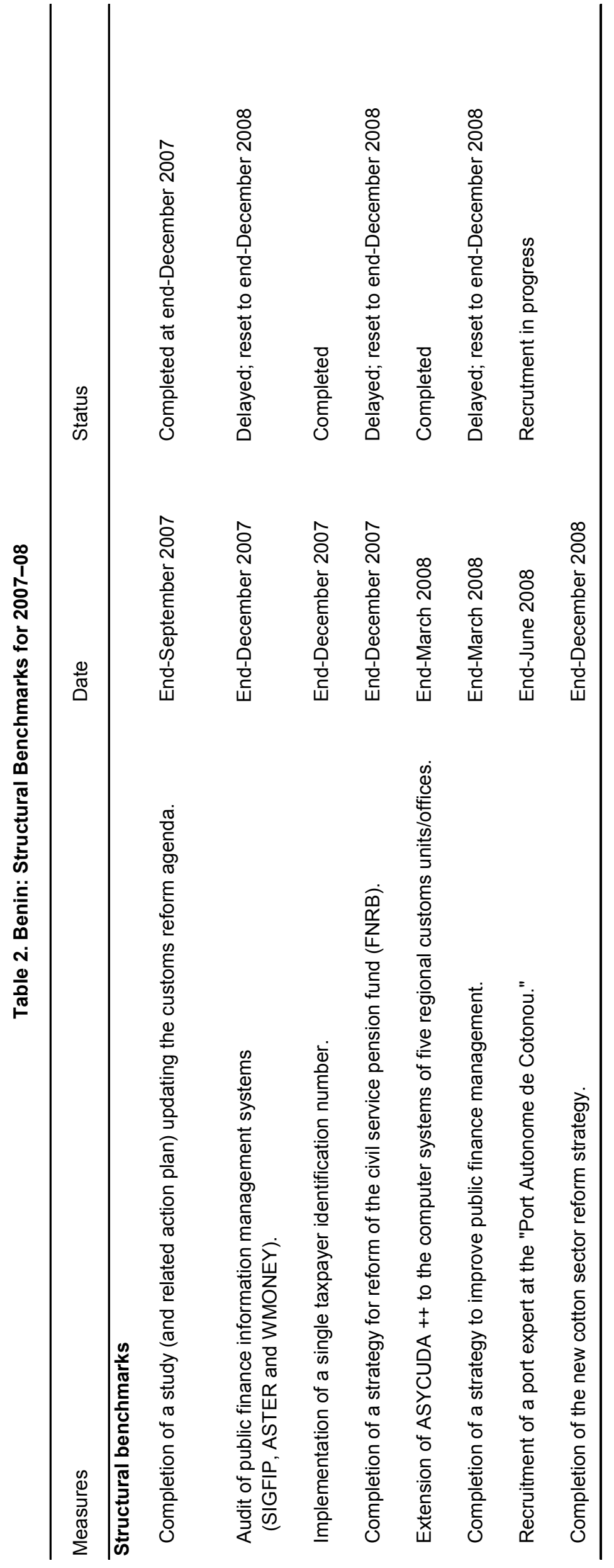




\title{
ApPendix I. Attachment II-Benin: TeChnical Memorandum OF Understanding
}

\author{
May 2008
}

1. This technical memorandum of understanding defines the quantitative and structural performance criteria and benchmarks for the program supported by the Poverty Reduction and Growth Facility (PRGF). It also sets out the frequency and deadlines for data reporting to the staff of the International Monetary Fund (IMF) for program-monitoring purposes.

\section{DEFINITIONS}

2. Unless otherwise indicated, the government is defined as the central government of the Republic of Benin and does not include local authorities, the central bank, or any other public entity with autonomous legal personality that is not included in the table of government financial operations (TOFE).

3. The definitions of "debt" and "concessional borrowing" for the purposes of this memorandum of understanding are as follows:

(a). As set out in Point 9 of the Guidelines on Performance Criteria with Respect to Foreign Borrowing (Executive Board Decision No. 6230-(79/140), amended by Executive Board Decision No. 12274-(00/85) (8/24/00), debt is understood to mean a current, that is, not contingent, liability created under a contractual agreement through the provision of value in the form of assets (including currency) or services, and which requires the obligor to make one or more payments in the form of assets (including currency) or services at some future points in time; these payments will discharge the principal and/or interest liabilities incurred under the contract. Debt can take a number of forms, the primary ones being as follows:

(i) loans, that is, advances of money to the obligor by the lender on the basis of an undertaking that the obligor will repay the funds in the future (including deposits, bonds, debentures, commercial loans, and buyers' credits) and temporary exchanges of assets that are equivalent to fully collateralized loans, under which the obligor is required to repay the funds, and usually pay interest, by repurchasing the collateral from the buyer in the future (such as repurchase agreements and official swap arrangements); (ii) suppliers' credits, that is, contracts where the supplier permits the obligor to defer payment until some time after the date on which the goods are delivered or services are provided; and (iii) leases, that is, arrangements under which property is provided that the lessee has the right to use for one or more specified period(s) of time, that are usually shorter than the total expected service life of the property, while the lessor retains the title to the property. For the purpose of this guideline, the debt is the present value (at the inception of the lease) of all lease payments expected to be made during the period of the arrangement, excluding those payments that cover the operation, repair, or maintenance of the property. Under this definition of debt set 
out above, arrears, penalties, and judicially awarded damages arising from failure to make payment under a contractual obligation that constitutes debt are debt. Failure to make payment on an obligation that is not considered debt under this definition (e.g., payment on delivery) will not give rise to debt.

(b). A loan is considered concessional if, on the date the contract is signed, the ratio of the present value of the loan, based on the reference interest rates, to the nominal value of the loan is less than 65 percent (i.e., a grant element exceeding 35 percent). The reference interest rates used in this assessment are the commercial interest reference rates (CIRRs) established by the Organization for Economic Cooperation and Development (OECD). For debts with a maturity exceeding 15 years, the ten-year reference interest rate published by the OECD is used to calculate the grant element. For shorter maturities, the six-month market reference rate is used.

\section{Quantitative Performance Criteria}

\section{A. Ceiling on Net Domestic Financing of the Government}

\section{Definition}

6. Net domestic financing of the government is defined as the sum of (i) net bank credit to the government, as defined below, and (ii) net nonbank financing of the government, including the proceeds from the sale of government assets net of the cost of structural reforms to which these proceeds are earmarked, including government treasury bills issued in CFAF on the regional financial market of the WAEMU.

7. Net Bank credit to the government is defined as the balance between the liabilities and claims of the government vis-à-vis the central bank and commercial banks. The scope of net credit to the government is that used by the Central Bank of West African States (BCEAO) and is consistent with the established Fund practice in this area. It implies a broader definition of government than that specified in paragraph 2. Claims of the government include the CFA franc cash balance, postal checking accounts, subordinated debt (obligations cautionnées), and all deposits with the BCEAO and commercial banks of public entities, with the exception of industrial or commercial public entities (EPIC) and public enterprises, which are excluded from the calculation. Government debt to the banking system includes all debt to these same financial institutions.

8. The net bank credit to the government and the net amount of government treasury bills and bonds issued in CFAF in the regional financial market of the WAEMU are calculated by the BCEAO, and nonbank financing is calculated by the Beninese Treasury, whose figures are those deemed valid in the context of the program. 
9. The ceiling on the net domestic financing of the government will be adjusted if disbursement of external budgetary assistance (excluding IMF financing and HIPC assistance) net of debt service obligations (excluding IMF repayment obligations) and payments of arrears, exceed or fall short of program forecasts. In the event of disbursement in larger than programmed amounts, the ceiling will be adjusted downward pro tanto by the excess disbursement, unless they are used to absorb domestic arrears. In contrast, if at the end of each quarter disbursements are less than the programmed amounts, the ceiling will be raised pro tanto by the amount of the shortfalls up to the limit (on a noncumulative basis) of CFAF 4.5 billion at end-June 2008, CFAF 10 billion at end-September 2008, and CFAF 18 billion at end-December 2008. The amount of external budgetary assistance provided is calculated from end-March 2008 onward. Budgetary assistance is defined as grants, loans, and debt relief (excluding project loans and grants, IMF resources, and debt relief under the enhanced Initiative for Heavily Indebted Poor Countries (HIPC Initiative) and the Multilateral Debt Relief Initiative (MDRI)).

\section{Performance criteria and indicators}

10. The ceiling on net domestic financing of the government is established as follows: CFAF 21.5 billion at end-March 2008, CFAF 13.8 billion at end-June 2008, CFAF 9.3 billion at end-September 2008, and CFAF -12.3 billion at end-December 2008. The ceiling is an indicative target at end-March 2008 and end-September 2008, and a performance criterion as at end-June 2008 and end-December 2008.

\section{Reporting requirement}

11. Detailed data on domestic financing to the government, including a detailed list of the bank account balances of other public entities, will be transmitted on a monthly basis within the four weeks following the end of the month. The definitive data will be provided within an additional four weeks after the provisional data have been reported.

\section{Definition}

\section{B. Narrow Primary Fiscal Balance}

12. The narrow primary fiscal balance is defined as the difference between total budgetary revenues (tax and nontax) and the budgetary expenses, less interests on the debt and capital expenditure financed by foreign grants and net loans.

\section{Performance criterion}


13. The ceiling on the narrow primary fiscal balance is established as follows: a surplus not lower than (i) CFAF 36.6 billion at end-March 2008, (ii) CFAF 33.5 billion at end-June 2008, (iii) CFAF 35 billion at end-September 2008, and CFAF 15.4 billion at end-December 2008. The ceiling is an indicative target at end-March 2008 and end-September 2008, and a performance criterion as at end-June 2008 and end-December 2008.

\section{Reporting requirement}

14. Provisional data on the narrow primary fiscal balance, including the data generated by the computerized budget management system (SIGFIP), will be transmitted on a monthly basis within the four weeks following the end of the month. The definitive data will be provided within an additional four weeks after the provisional data have been reported.

\section{Accumulation of New Domestic Payments Arrears on Government Obligations}

\section{Definition}

15. Domestic payments arrears on government obligations are defined as outstanding debt owed by the government to residents due following the expiration of a 90-day grace period, unless specified otherwise, but not paid, and any financial obligation of the government verified as such by the government (including any government debt). The Caisse Autonome d'Amortissement (CAA-the government debt management agency) and the Treasury keep and update the inventory of domestic debt arrears on government obligations and maintain records of their payments.

\section{Performance criterion}

16. The government undertakes not to accumulate any new domestic payments arrears on government debt. For obligations other than government debt, the government undertakes not to accumulate arrears beyond six months. The non accumulation of domestic payments arrears will be monitored on a continuous basis throughout the program period.

\section{Reporting requirement}

17. Data on outstanding balance, accumulation, and repayment of domestic payments arrears on government obligations will be provided monthly within eight weeks following the end of each month. 


\section{Nonaccumulation of External Public Payments Arrears}

\section{Definition}

18. External public payments arrears are defined as the sum of payments owed to non residents due and not paid on debt of the government and on external debt guaranteed by the government. The definition of "debt" provided in paragraph 3 applies here.

\section{Performance criterion}

19. Under the program, the government will not accumulate external payments arrears, with the exception of arrears arising from debt under renegotiation or being rescheduled. The performance criterion on the nonaccumulation of external public payments arrears will be monitored on a continuous basis throughout the program period.

\section{E. Ceiling on Nonconcessional External Debt with a Maturity of One-Year or More Newly Contracted or Guaranteed by the Government}

\section{Definition}

20. This performance criterion applies not only to debt as defined in point No. 9 of the Guidelines on Performance Criteria with Respect to Foreign Borrowing (Executive Board Decision No. 6230-(79/140), amended by Executive Board Decision No. 12274-(00/85) $(8 / 24 / 00)$, but also to commitments contracted or guaranteed (including lease-purchase agreements) for which no value has yet been received. The external debt excludes treasury bills and bonds issued in CFAF on the regional financial market of the West African Economic and Monetary Union.

21. The concept of "government" for the purposes of this performance criterion includes government as defined in paragraph 2, public institutions of an administrative nature (EPA), public institutions of a scientific and/or technical nature, public institutions of a professional nature, and local governments.

\section{Performance criterion}

22. Nonconcessional external borrowing and guaranteeing will be zero throughout the 2007 program. 


\section{Reporting requirement}

23. Information on any borrowing (including terms of loans and creditors) contracted or guaranteed by the government shall be transmitted each month within four weeks following the end of the month.

\section{F. Ceiling on Short-Term External Debt Newly Contracted or Guaranteed by the Government}

\section{Definition}

24. The definitions in paragraphs 18 and 19 also apply to this performance criterion.

25. Short-term external debt is debt with a contractual term of less than one year. Importrelated loans and debt-relief operations are excluded from this performance criterion.

\section{Performance criterion}

26. In the context of the program, the government will not contract or guarantee shortterm nonconcessional external debt.

27. As of December 31, 2006, the government of Benin has no short-term external debt.

\section{QUANTITATIVE INDICATORS}

\section{A. Floor on Government's Revenues}

\section{Definition}

28. Government revenues are defined as those that appear in the government's financial operations table (TOFE).

\section{Indicative targets}

29. Indicative targets for total government revenues are set as follows: CFAF 142.7 billion at end-March 2008, CFAF 266.8 billion at end-June 2008, CFAF 396.0 billion at endSeptember 2008, and CFAF 530.7 billion at end-December 2008 (cumulative since endDecember 2007).

\section{Reporting requirement}


30. The government shall report its revenues to IMF staff each month in the context of the TOFE and before the end of the following month.

\section{Definition}

\section{B. Ceiling on the Wage Bill}

31. The wage bill includes all public expenditure on wages, bonuses, and other benefit or allowances granted civil servants employed by the government, the military and other security forces, and includes expenditure with respect to special contracts and other permanent or temporary employment with the government. The wage bill, therefore, excludes the salaries related to projects financed by foreign donors as well as the transfers related to the salaries of the teachers at the level of local municipalities.

\section{Indicative targets}

32. The quantitative benchmarks are defined as cumulative amounts after end-December 2006 for criteria set in 2007 and after end-December 2007 for criteria set in 2008. The civil service wage bill quarterly ceilings are CFAF 36.6 billion at end-March 2008, CFAF 76.0 billion at end-June 2008, CFAF 114.8 billion at end-September 2008, and CFAF 164.6 billion at end-December 2008 (Staff report, Table 4 and MEFP, Table 1).

\section{Reporting requirement}

33. The government shall report the wage bill to IMF staff each month in the context of the TOFE.

\section{STRUCTURAL BENCHMARKS}

34. The government will complete the following actions (MEFP, Table 2):

- $\quad$ Audit of public finance information management systems (SIGFIP, ASTER and WMONEY);

- $\quad$ Completion of a strategy for reform of the civil service pension fund (FNRB);

- $\quad$ Extension of ASYCUDA ++ to the computer systems of five regional customs units/offices;

- $\quad$ Completion of a strategy to improve public finance management;

- $\quad$ Recruitment of port expert at the "Port Autonome de Cotonou;" 
- Completion of a new cotton sector reform strategy.

\section{Other Data Requirements for Program Monitoring}

\section{Public Finance}

35. The government will provide to the Fund the following:

- Detailed monthly revenue and expenditure estimates, including social expenditures, payments on arrears, and HIPC Initiative-related expenditure;

- $\quad$ Monthly data on domestic financing (bank and nonbank) of the budget (including government bonds held by the nonbank public), which will be transmitted on a monthly basis within four weeks of the end of each month;

- Data on the implementation of the development budget, with detailed information on the sources of financing, which will be transmitted on a quarterly basis within 4 weeks of the end of each quarter.

\section{Monetary Sector}

36. The government will provide to the Fund the following data on a monthly basis within eight weeks of the end of the month:

- The consolidated balance sheets of deposit money banks, and the individual bank balance sheet, as needed;

- $\quad$ The monetary survey;

- $\quad$ Lending and deposit rates;

- $\quad$ the standard bank supervision indicators for banks, as well as those for nonbank financial institutions and for individual institutions, as needed.

\section{E. External Sector}

37. The government will provide to the Fund the following data within 12 weeks of the end of each quarter:

- $\quad$ Export and import price and volume data; 
- $\quad$ Other balance of payments data, including data on services, private transfers, official transfers, and capital account transactions.

\section{F. Real Sector}

38. The government will provide to the Fund:

- $\quad$ Monthly disaggregated consumer price indices will be transmitted on a monthly basis within two weeks of the end of each month;

- Any revisions to the national accounts data will be transmitted within eight weeks of the date of revision.

\section{G. Structural Reforms and Other Data Requirements}

39. The government will provide to the Fund:

- Documentation of all decisions, laws, decrees, orders, and circulars undertaken by the government pertaining to the economy of Benin will be submitted within ten days of publication;

- $\quad$ All studies and research papers related to the economy of Benin will be submitted within two weeks of publication. 


\section{INTERNATIONAL MONETARY FUND}

BENIN

Staff Report for the 2008 Article IV Consultation, Fourth Review Under the ThreeYear Arrangement Under the Poverty Reduction and Growth Facility, and Request for Augmentation of Access

\section{Informational Annex}

Prepared by the African Department

May 30, 2008

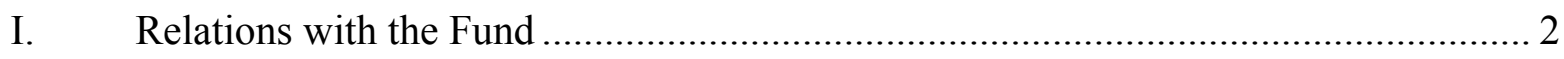

II. Relations with the World Bank Group......................................................... 8

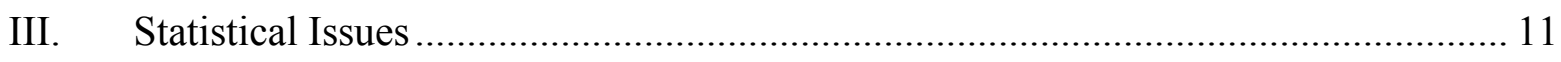




\section{APPENDIX I-RELATIONS WITH THE FUND}

(As of April 30, 2008)

I. Membership Status: Joined: July 10, 1963;

$\underline{\text { Article VIII }}$

II. General Resources Account:

SDR Million

61.90

\%Quota

Quota

59.72

100.00

Fund holdings of currency

2.19

96.48

$\underline{\text { Reserve Position }}$

Holdings Exchange Rate

\section{SDR Department:}

SDR Million

\%Allocation

Net cumulative allocation

9.41

100.00

Holdings

0.02

1.23

IV. Outstanding Purchases and Loans:

SDR Million

\%Quota

PRGF Arrangements

3.52

5.69

\section{Latest Financial Arrangements:}

\begin{tabular}{|c|c|c|c|c|}
\hline Type & $\begin{array}{c}\text { Date of } \\
\text { Arrangement }\end{array}$ & $\begin{array}{l}\text { Expiration } \\
\text { Date }\end{array}$ & $\begin{array}{l}\text { Amount Approved } \\
\text { (SDR Million) }\end{array}$ & $\begin{array}{l}\text { Amount Drawn } \\
\text { (SDR Million) }\end{array}$ \\
\hline PRGF & Aug 05, 2005 & Aug $0 \overline{4,2009}$ & 6.19 & 3.52 \\
\hline PRGF & Jul 17, 2000 & Mar 31, 2004 & 27.00 & 27.00 \\
\hline PRGF & Aug 28, 1996 & Jul 16, 2000 & 27.18 & 16.31 \\
\hline
\end{tabular}

VI. Projected Payments to Fund ${ }^{1 /}$

(SDR Million; based on existing use of resources and present holdings of SDRs):

Principal

Charges/Interest

Total

\begin{tabular}{lllll}
\multicolumn{5}{c}{ Forthcoming } \\
\hline$\underline{2008}$ & $\underline{2009}$ & $\underline{2010}$ & $\frac{2011}{0.18}$ & $\frac{2012}{0.44}$ \\
$\underline{0.21}$ & $\underline{0.27}$ & $\underline{0.27}$ & $\underline{0.27}$ & $\underline{0.27}$ \\
$\underline{0.21}$ & $\underline{0.27}$ & $\underline{0.27}$ & $\underline{0.45}$ & $\underline{0.71}$
\end{tabular}

${ }^{1 /}$ When a member has overdue financial obligations outstanding for more than three months; the amount of such arrears will be shown in this section.

\section{Implementation of HIPC Initiative:}

I. Commitment of HIPC assistance

Enhanced

Decision point date

Framework

Assistance committed

Jul 2000

by all creditors (US\$ Million) ${ }^{1 /}$

265.00

Of which: IMF assistance (US\$ million)

(SDR equivalent in millions)

18.40

Completion point date

Mar 2003 
II. Disbursement of IMF assistance (SDR Million)

Assistance disbursed to the member

Interim assistance

11.04

Completion point balance

Additional disbursement of interest income ${ }^{2 /}$

Total disbursements

${ }^{1 /}$ Assistance committed under the original framework is expressed in net present value (NPV) terms at the completion point, and assistance committed under the enhanced framework is expressed in NPV terms at the decision point. Hence these two amounts can not be added.

${ }^{2 /}$ Under the enhanced framework, an additional disbursement is made at the completion point corresponding to interest income earned on the amount committed at the decision point but not disbursed during the interim period.

\section{Implementation of Multilateral Debt Relief Initiative (MDRI):}

I. MDRI-eligible debt (SDR Million) $)^{1 /}$

Financed by: MDRI Trust

Remaining HIPC resources

II. Debt Relief by Facility (SDR Million)

\begin{tabular}{|c|c|c|c|}
\hline \multirow[b]{2}{*}{ Delivery } & \multicolumn{3}{|c|}{ Eligible Debt } \\
\hline & GRA & PRGF & Total \\
\hline January 2006 & N/A & 36.06 & 36.06 \\
\hline
\end{tabular}

${ }^{1 /}$ The MDRI provides 100 percent debt relief to eligible member countries that qualified for the assistance. Grant assistance from the MDRI Trust and HIPC resources provide debt relief to cover the full stock of debt owed to the Fund as of end-2004 that remains outstanding at the time the member qualifies for such debt relief.

Decision point - point at which the IMF and the World Bank determine whether a country qualifies for assistance under the HIPC Initiative and decide on the amount of assistance to be committed.

Interim assistance - amount disbursed to a country during the period between decision and completion points, up to 20 percent annually and 60 percent in total of the assistance committed at the decision point (or 25 percent and 75 percent, respectively, in exceptional circumstances).

Completion point - point at which a country receives the remaining balance of its assistance committed at the decision point, together with an additional disbursement of interest income as defined in footnote 2 above. The timing of the completion point is linked to the implementation of pre-agreed key structural reforms (i.e., floating completion point). 


\section{Safeguards Assessments:}

The Central Bank of West African States (BCEAO) is the common central bank of the countries of the West African Economic and Monetary Union, which includes Benin. The most recent safeguards assessment of the BCEAO was completed on November 4, 2005. The assessment indicated progress has been made in strengthening the bank's safeguards framework since the 2002 assessment and identified some areas where further steps would help solidify it.

The BCEAO now publishes a full set of audited financial statements and improvements have been made to move financial reporting closer to International Financial Reporting Standards (IFRS). Furthermore, an internal audit charter has been put in place, mechanisms for improving risk management have been established, and follow-up on internal and external audit recommendations has been strengthened.

The results of continuous safeguards monitoring indicate that while certain vulnerabilities remain in internal control systems and legal structure, there has been some progress in other areas, including through: (i) improving the external audit process by adopting a multi-year audit program; (ii) establishing an audit committee; (iii) expanding disclosures on financial positions of WAEMU countries with the Fund in the notes to the annual financial statements; and (iv) further strengthening of the effectiveness of the internal audit function.

\section{Exchange Arrangement:}

Benin is a member of the West African Economic and Monetary Union (WAEMU) and has no separate legal tender. The union's common currency, the CFA franc, is pegged to the Euro at a rate of CFAF $655.957=$ EUR 1, consistent with the official conversions rate of the French franc to the Euro and the previous fixed rate of the CFA franc to the French franc of CFAF $100=$ F 1. On April 28, 2006, the rate of the CFA franc in terms of SDR was CFAF $769.68=$ SDR 1.0. Effective January 1, 2007, the exchange arrangement of the WAEMU countries has been reclassified to the category of conventional pegged arrangement from the category of exchange arrangement with no separate legal tender. The new classification is based on the behavior of the common currency, whereas the previous classification was based on the lack of a separate legal tender. The new classification thus only reflects a definitional change, and is not based on a judgment that there has been a substantive change in the exchange regime or other policies of the currency union or its members. The exchange system common to all member countries of the WAMU is free of restrictions on payments and transfers for current international transactions subject to Fund jurisdiction. 


\section{Article IV Consultations:}

The last Article IV consultation discussions were held in Cotonou during August 9-23, 2006. The staff report (CR/07/6; 01/04/07) and selected issues paper were discussed by the Executive Board, and the 2006 Article IV consultation concluded, on November 27, 2006.

\section{ROSC Assessment:}

An FAD mission conducted the fiscal module of a Report on Observance of Standards and Codes (ROSC) in May 2001. The mission recommended the adoption of a three-year action plan containing measures to improve expenditure management. The mission also identified a list of actions to be taken quickly to ensure that the authorities were able to monitor budget execution. The ROSC fiscal transparency module for Benin was circulated to the Board on June 6, 2002 (CR/02/217).

XIII. Technical Assistance

\section{A. Headquarters}

\begin{tabular}{llll}
\hline Department & $\begin{array}{l}\text { Type of } \\
\text { Assistance }\end{array}$ & Time of Delivery & Purpose \\
\hline FAD & $\begin{array}{l}\text { Resident } \\
\text { expert }\end{array}$ & $\begin{array}{l}\text { September 1989- } \\
\text { September 1994 }\end{array}$ & $\begin{array}{l}\text { Advising Minister of Finance on tax } \\
\text { reform }\end{array}$ \\
FAD & $\begin{array}{l}\text { Resident } \\
\text { expert }\end{array}$ & $\begin{array}{l}\text { November 1990- } \\
\text { November 1992 }\end{array}$ & $\begin{array}{l}\text { Advising Minister of Finance on } \\
\text { budgetary procedures }\end{array}$ \\
STA & $\begin{array}{l}\text { Technical } \\
\text { assistance }\end{array}$ & February 4-17, 1998 & $\begin{array}{l}\text { Formulating a strategy to improve } \\
\text { statistical organization and } \\
\text { management of the Central Bank of } \\
\text { West African States. }\end{array}$ \\
FAD & $\begin{array}{l}\text { Technical } \\
\text { assistance }\end{array}$ & September 7-22, 1998 & $\begin{array}{l}\text { Advising Minister of Finance on tax } \\
\text { administration. }\end{array}$ \\
Technical & April 17-28, 2000 & $\begin{array}{l}\text { Devising new questionnaires for } \\
\text { balance of payments statistics and } \\
\text { reactivating the banking settlements } \\
\text { reporting system. }\end{array}$ \\
& & &
\end{tabular}




\begin{tabular}{|c|c|c|c|}
\hline Department & $\begin{array}{l}\text { Type of } \\
\text { Assistance }\end{array}$ & Time of Delivery & Purpose \\
\hline FAD & $\begin{array}{l}\text { Technical } \\
\text { assistance }\end{array}$ & April 25-May 5, 2000 & $\begin{array}{l}\text { Advising Minister of Finance on tax } \\
\text { administration }\end{array}$ \\
\hline STA & $\begin{array}{l}\text { Technical } \\
\text { assistance }\end{array}$ & May 7-11, 2000 & $\begin{array}{l}\text { Improving the collection, } \\
\text { compilation, and dissemination of } \\
\text { data on monetary and financial } \\
\text { statistics }\end{array}$ \\
\hline FAD & $\begin{array}{l}\text { Technical } \\
\text { assistance }\end{array}$ & May 16-29, 2001 & $\begin{array}{l}\text { Preparing a fiscal transparency } \\
\text { module of a ROSC and assessment } \\
\text { of capacity to monitor HIPC } \\
\text { Initiative resources. }\end{array}$ \\
\hline FAD & $\begin{array}{l}\text { Technical } \\
\text { assistance }\end{array}$ & $\begin{array}{l}\text { September 11-25, } \\
2002\end{array}$ & $\begin{array}{l}\text { Helping the authorities strengthen } \\
\text { domestic revenue and customs } \\
\text { administrations. }\end{array}$ \\
\hline FAD & $\begin{array}{l}\text { Technical } \\
\text { assistance }\end{array}$ & $\begin{array}{l}\text { August } 23- \\
\text { September } 3,2003\end{array}$ & $\begin{array}{l}\text { Evaluating public expenditure } \\
\text { management reforms and monitoring } \\
\text { capacity of poverty- reducing } \\
\text { expenditures. }\end{array}$ \\
\hline
\end{tabular}

FAD Technical October 22-

assistance November 5, 2003

Evaluating the implementation of the action plan to strengthen domestic revenue and customs administrations

STA Technical November 11assistance November 24, 2004

Assessing the quality of balance of payment statistics.

LEG Technical April 24-26, 2006 assistance

Providing in-depth training on the AML/CFT framework

FAD $\begin{aligned} & \text { Technical } \\ & \text { assistance }\end{aligned}$ October 10-23, 2006

Review of status of implementation of reforms to modernize the tax and customs administrations 


\begin{tabular}{|c|c|c|c|}
\hline Department & $\begin{array}{l}\text { Type of } \\
\text { Assistance }\end{array}$ & Time of Delivery & Purpose \\
\hline \multirow[t]{2}{*}{ FAD } & $\begin{array}{l}\text { Technical } \\
\text { assistance }\end{array}$ & $\begin{array}{l}\text { October 30- } \\
\text { November 13, } 2006\end{array}$ & $\begin{array}{l}\text { PFM diagnostic and preparation of a } \\
\text { reform action plan }\end{array}$ \\
\hline & \multicolumn{3}{|c|}{ AFRITAC WEST } \\
\hline FAD & $\begin{array}{l}\text { Technical } \\
\text { assistance }\end{array}$ & 2006,2007 & Customs Administration \\
\hline FAD & $\begin{array}{l}\text { Technical } \\
\text { assistance }\end{array}$ & 2006,2007 & Public Expenditure Management \\
\hline FAD & $\begin{array}{l}\text { Technical } \\
\text { assistance }\end{array}$ & $2006,2007,2008$ & Tax Administration \\
\hline MCM & $\begin{array}{l}\text { Technical } \\
\text { assistance }\end{array}$ & 2006,2007 & Bank Supervision and Regulation \\
\hline MCM & $\begin{array}{l}\text { Technical } \\
\text { assistance }\end{array}$ & 2007,2008 & Public Debt and Debt Sustainability \\
\hline STA & $\begin{array}{l}\text { Technical } \\
\text { assistance }\end{array}$ & 2006 & Government Finance Statistics \\
\hline STA & $\begin{array}{l}\text { Technical } \\
\text { assistance }\end{array}$ & 2007,2008 & Multisector Statistics \\
\hline STA & $\begin{array}{l}\text { Technical } \\
\text { assistance }\end{array}$ & 2006 & National Accounts Statistics \\
\hline STA & $\begin{array}{l}\text { Technical } \\
\text { assistance }\end{array}$ & 2006,2008 & Real Sector Statistics \\
\hline
\end{tabular}

\section{Resident Representative:}

Mr. Yao has been the Resident Representative since September 26, 2005. 


\section{APPENDIX II-RELATIONS WITH THE WORLD BANK GROUP}

\section{Partnership in Benin's development strategy}

1. Benin's revised poverty reduction strategy paper (PRSP) was finalized in April 2007 and discussed at the Bank and Fund Boards in June 2007. The PRSP provides a framework for aligning donor assistance programs, including those of the Bank and the Fund, with the country's poverty reduction efforts.

2. Public expenditure management reform has been an important focus of the Bank's assistance program. In close collaboration with the Fund and other donors, the Bank has provided technical and financial assistance to the government's reform efforts in this area. The Bank has also been in the lead in helping Benin strengthen the provision of basic social services, most importantly in the education and health sectors, pursuing a divestiture program in the utility and infrastructure sectors, and enhancing the competitiveness of the cotton sector.

\section{IMF-World Bank collaboration in specific areas}

3. Common objectives and joint support for Benin's PRSP and the Initiative for Heavily Indebted Poor Countries (HIPC Initiative) processes have increased collaboration between the Fund and Bank in recent years. The Bank and Fund teams are closely coordinating their policy advice to the authorities. There is also close coordination in the determination of structural conditionality

4. Private sector development and infrastructure. The Bank has supported Benin's program for economic growth through different projects. Assistance for the privatization of the telecommunications company and for improving the Cotonou port operations is provided through the Private Sector Development Project. The Bank supports private participation in the electricity branch of the SBEE through the Energy Services Delivery Project which was approved by the Bank's Board on July 6, 2004. The privatization of SONAPRA's ginning mills, along with reforms aimed at liberalizing the sector and strengthening the capacity of producers is supported by the Cotton Sector Project.

5. Fiscal policy and fiduciary framework. Fiscal consolidation was a key objective of the Fund-supported PRGF arrangement. The Bank is focusing on improving the efficiency, transparency and accountability of public expenditures. In addition, the Bank is helping to strengthen Benin's fiduciary framework through analytical and advisory activities (AAA), such as the updates of the Country Procurement Assessment Report (CPAR) and Country Financial Accountability Assessment (CFAA), and the governance and anti-corruption survey. The PRSC series also supports a comprehensive action plan for fiduciary and public procurement reform. 
6. Poverty reduction strategy. Together with other external development partners, the Bank and Fund have jointly provided assistance to the government in the preparation of Benin's revised PRSP. The PRSP was discussed at Bank and Fund Boards in June 2007, together with a joint staff assessment prepared by Bank and Fund staffs. Both institutions will continue to jointly advise the authorities on the refinement, implementation, monitoring, and evaluation of the strategy. The latest PRSP progress report was circulated to Bank and Fund Boards in June 2008.

7. Debt sustainability. The Bank and the Fund jointly supported the government's efforts to reach the HIPC Initiative completion point in March 2003 and qualification for the MDRI. In the context of the new PRGF program, Bank and Fund staffs regularly update the debt sustainability analysis for Benin, in close collaboration with the authorities.

8. Financial sector policy. The Fund has supported the government's efforts to strengthen Benin's financial sector. As part of the Private Sector Development Project, the Bank has been providing support to two major microfinance institutions. A financial sector review was completed and the report was released in July 2004.

\section{World Bank strategy}

9. The overriding objective of the Bank's Country Assistance Strategy (CAS) discussed at its Board on July 3, 2003 is to help Benin reverse the recent trends of limited poverty reduction and improve economic growth. Progress in reducing poverty and attaining the Millennium Development Goals (MDGs) requires further deepening of cotton sector reforms, strengthening efforts toward diversifying the economy, making tangible progress in the social sectors, building effective and responsive public institutions, promoting gender equality, and strengthening collaboration with the private sector and civil society. The CAS describes a program of financial assistance and nonlending services as the Bank's contribution to addressing these challenges, and it supports the implementation of the PRSP. A new CAS is scheduled to be prepared in 2008 based on the revised PRSP.

10. To advance public sector management reforms aimed at increasing efficiency in the use of public resources, the Bank will continue its support of Benin's public expenditure reform through financial and technical support. Annual single-tranche PRSCs are envisaged to remain a key vehicle for Bank support to the country. A first PRSC was presented to the Bank's Board in March 2004, the second in June 2005, the third in November 2006 and the fourth in June 2007. The series is expected to continue to support the PRSP pillars, with components on economic growth, service delivery, and governance.

11. PRSP implementation monitoring has fostered collaboration between the Bank and other development partners, including civil society organizations. Donors have signaled their willingness to align their assistance programs to the PRSP and some of them have engaged in budget support operations, in close coordination with the Bank's PRSC preparation process. 
Benin: Status of World Bank Portfolio

(In millions of U.S. dollars, as of April 30, 2008)

\begin{tabular}{lccc}
\hline Project & Effectiveness Date & $\begin{array}{c}\text { Original } \\
\text { Principal (IDA) }\end{array}$ & $\begin{array}{c}\text { Undisbursed } \\
\text { (IDA) }\end{array}$ \\
\hline Competitiveness and Growth & & & \\
Opportunity Project & Not yet Effective & 25.0 & 25.0 \\
GEF Com. Based Coastal & Not yet effective & 4.3 & 4.3 \\
HIV/AIDS Multisector & $1 / 09 / 08$ & 35.0 & 34.9 \\
Cotton Sector Reform & $9 / 12 / 02$ & 18.0 & 3.00 \\
Energy Service Delivery & $4 / 25 / 05$ & 45.0 & 39.3 \\
National CDD & $5 / 2 / 05$ & 50.0 & 29.5 \\
$2^{\text {nd }}$ Decentralized Cities & $3 / 8 / 06$ & 35.0 & 19.3 \\
GEF Forests \& Adj. Land & $3 / 27 / 07$ & 6.0 & 5.3 \\
Malaria & $3 / 16 / 07$ & 31.0 & 22.3 \\
\multicolumn{1}{c}{ Total } & & & \\
\hline
\end{tabular}

12. As of April 30, 2008, the Bank lending portfolio consists of nine operations, including 2 GEF operations and the newly approved Competitiveness and Growth Opportunity Project. Net commitments reach US\$249.3 million with an undisbursed balance of US\$182.9 million (see table above).

Prepared by World Bank Staff. Questions may be asked to Ms. Antonella Bassani, Acting Country Director for Benin, (202) 473-1468; or Ms. Nancy Benjamin, Economist for Benin, (202) 473-0189. 


\section{APPENDIX III-STATISTICAL ISSUES}

(As of May 1, 2008)

1. Economic data are broadly adequate for both program monitoring and surveillance, despite weaknesses in the areas of national accounts, public finance, monetary statistics, and balance of payments. Benin has participated in the General Data Dissemination System (GDDS) since 2001. Most sectoral metadata are due to be updated. STA technical assistance (funded by the Japanese government) is being offered to the eight member countries of the West African Economic and Monetary Union (WAEMU) to assist with implementation of plans for the improvement of their statistical systems. A Fund regional statistical advisor initiated a program of assistance in government finance statistics, which is now managed by the West Africa Regional Technical Assistance Center (AFRITAC West). A real sector statistics improvement program, conducted in collaboration with the regional statistical office AFRISTAT initiated in May 2002, is currently being implemented.

\section{Real sector statistics}

2. The country participates in WAEMU's harmonization of statistical methodologies through the multilateral surveillance process, currently seeking regional improvements in the area of national accounts. Under the GDDS project for the AFRITAC West countries to implement the 1993 SNA, a statistical register and an industrial production index are being developed. In April 2008, an AFRITAC West mission coincided with the finalization of the national accounts estimates for 2001. During the mission, a revised work program, including actions to accelerate the compilation of the revised accounts, was discussed with the authorities. The national accounts estimates for the new base year are to be disseminated by end-2008. Consumer prices are measured using the WAEMU harmonized consumer price index.

\section{Government finance statistics}

3. Monthly and annual government finance statistics are compiled by the Ministry of Finance (MoF) with a one to three month lag for monthly data, based on information provided by the budget, customs, tax, and treasury directorates. The MoF prepares a monthly reconciliation of spending commitments made by the budget directorate and payments made by the treasury. However, no final budget or treasury accounts are published at the end of the fiscal year. Data compilation and reporting have been strengthened as a result of a series of AFRITAC West/STA technical assistance missions and training during the period 2005 to the present. The authorities provided data for publication in the 2006 and 2007 issues of the Government Finance Statistics Yearbook (GFSY) The coverage of these data are limited to the "Budgetary Central Government," but covering only eight of the principal ministries and other units of central government. 


\section{Monetary and financial statistics}

4. Monetary and financial statistics are compiled and disseminated by the regional Central Bank of West African States (BCEAO). In response to AFR and STA request, the BCEAO made substantial revisions in 2005 to the estimates of banknotes in circulation in member states resulting from cross-border banknote movement. These revisions were due to changes in the method to estimate currency in circulation in the WAEMU countries. The revised method, based on updated sorting coefficients (initially established in 1990), has been applied retroactively from December 2003. The BCEAO is using sorting coefficients to evaluate the amounts of currency issued by each country, which in turn, are used to estimate currency in circulation and to adjust the net foreign assets of each member country.

5. In August 2006, as part of the authorities' efforts to implement the MFSM's methodology, the BCEAO reported to STA test monetary data for June 2006 for all member countries using Standardized Report Forms (1SR-central bank, 2SR-other depository corporations, and 5SR-monetary aggregates). In response to STA's comments on the test data, the BCEAO has recently provided clarifications but only on the form 1SR. STA's efforts to advance the work on SRFs is supported by AFR in the context of its surveillance work with the WAEMU.

\section{Balance of payments}

6. Since December 1998, the responsibility for compiling and disseminating balance of payments statistics has been formally assigned to the BCEAO by area-wide legislation adopted by the countries participating in the WAEMU. The national agency of the BCEAO in Cotonou is responsible for compiling and disseminating balance of payments statistics, and the BCEAO headquarters in Dakar for delineating the methodology and calculating the international reserves managed on behalf of the participating countries.

7. Data consistency has significantly improved over the past few years, with a full transition to the Balance of Payments Manual, Fifth Edition (BPM5). The BCEAO national agency typically disseminates balance of payments statistics with a more than one year lag, exceeding GDDS guidelines. The BCEAO also compiles and disseminates the annual data of the international investment position data with an 18-month lag.

8. Regarding trade data, the ASYCUDA customs computer system is now installed in all main border customs houses; ASYCUDA ++ is installed in the port and at the airport. The interconnection between the computer systems of the main departments of Customs has not been completed yet and the monitoring of import data needs to be stepped up.

9. Further improvement in the data for services and transfers (especially workers' remittances) will depend on the intensification of the contacts with reporting bodies. The authorities' commitment to strengthen the human and technical resources should be enhanced. 
10. Concerning the financial account, the foreign assets of the private nonbanking sector are still not well covered, especially the assets of WAEMU residents, which are obtained through partial surveys of residents' foreign assets. The organization of an exhaustive annual survey of foreign direct investment transactions is still at a very preliminary stage. The BCEAO has recently updated the compilation of commercial bank data on payments involving nonresidents; however these data are not used to produce annual balance of payments estimates, but rather to assess existing information.

11. A technical assistance mission in November 2004 found that human resources devoted to balance of payments statistics by the national agency of the BCEAO are insufficient, but that the reporting system was well developed and consistent. Regarding trade in goods, and the recording of informal transactions, the statistical adjustments to Customs data appear methodologically sound; however, the hypotheses and reference bases on which they rest are largely untested. Other weaknesses in the current account concern the underestimation of transportation services and overestimation of current transfers. In the financial account, the coverage of direct investment is poor while unsorted banknotes impacts on the compilation of net external assets in the balance of payments and international investment position statistics.

\section{Poverty data}

12. Major methodological weaknesses remain regarding poverty data. In particular, the methodology used in the household surveys raises concerns about the treatment of the nonfood expenditure share in the calculation of the poverty line, the division of the country into 12 agro-ecological zones, and the comparability of poverty statistics across urban and rural areas and across time. The authorities are implementing an action plan to address these methodological issues. The authorities have completed a modular survey of household living conditions to update the poverty profile in the context of the preparation of the second PRSP.

\section{External debt}

13. The Caisse Autonome d'Amortissements (CAA) is responsible for signing international loan agreements, maintaining the debt database, and servicing the government's external debt obligations. Since 1995, the CAA has been using the Commonwealth Secretariat Debt Recording and Management System (CS-DRMS) to record and manage the debt. For the majority of creditors, the CAA's database is fairly comprehensive and up-todate, and contains accurate stock data, as well as projected debt-service flows, on a loan-byloan basis. For a small number of creditors, however, regular statements are not received. 
14

Benin: Table of Common Indicators Required for Surveillance

(As of May 1, 2008)

\begin{tabular}{|c|c|c|c|c|c|}
\hline & $\begin{array}{l}\text { Date of latest } \\
\text { observation }\end{array}$ & $\begin{array}{l}\text { Date } \\
\text { received }\end{array}$ & $\begin{array}{l}\text { Frequency of } \\
\text { Data }^{6}\end{array}$ & $\begin{array}{l}\text { Frequency of } \\
\text { Reporting }^{6}\end{array}$ & $\begin{array}{l}\text { Frequency of } \\
\text { publication }^{6}\end{array}$ \\
\hline Exchange Rates & Current & Current & D & $\mathrm{D}$ & M \\
\hline $\begin{array}{l}\text { International Reserve Assets and } \\
\text { Reserve Liabilities of the Monetary } \\
\text { Authorities }^{1}\end{array}$ & $07 / 07$ & $10 / 07$ & M & M & M \\
\hline Reserve/Base Money & $12 / 07$ & $3 / 08$ & M & M & M \\
\hline Broad Money & $12 / 07$ & $3 / 08$ & M & M & M \\
\hline Central Bank Balance Sheet & $12 / 07$ & $3 / 08$ & M & M & M \\
\hline $\begin{array}{l}\text { Consolidated Balance Sheet of the } \\
\text { Banking System }\end{array}$ & $12 / 07$ & $3 / 08$ & M & M & M \\
\hline Interest Rates $^{2}$ & $1 / 08$ & $2 / 08$ & M & M & M \\
\hline Consumer Price Index & $03 / 08$ & $03 / 08$ & M & M & M \\
\hline $\begin{array}{l}\text { Revenue, Expenditure, Balance and } \\
\text { Composition of Financing }{ }^{3}- \\
\text { General Government }^{4}\end{array}$ & NA & NA & NA & NA & NA \\
\hline $\begin{array}{l}\text { Revenue, Expenditure, Balance and } \\
\text { Composition of Financing }{ }^{3}-\text { Central } \\
\text { Government }\end{array}$ & $12 / 06$ & $3 / 07$ & M & M & A \\
\hline $\begin{array}{l}\text { Stocks of Central Government and } \\
\text { Central Government-Guaranteed } \\
\text { Debt }^{5}\end{array}$ & NA & NA & NA & NA & NA \\
\hline External Current Account Balance & 2006 & $12 / 07$ & A & A & A \\
\hline $\begin{array}{l}\text { Exports and Imports of Goods and } \\
\text { Services }\end{array}$ & 2006 & $12 / 07$ & $A$ & Q & A \\
\hline GDP/GNP & 2006 & $03 / 08$ & $A$ & $A$ & $A$ \\
\hline
\end{tabular}

${ }^{1}$ Includes reserve assets pledged or otherwise encumbered as well as net derivative positions.

${ }^{2}$ Both market-based and officially determined, including discount rates, money market rates, rates on treasury bills, notes and bonds.

${ }^{3}$ Foreign domestic bank and domestic nonbank financing.

${ }^{4}$ The general government consists of the central government (budgetary funds, extra budgetary funds, and social security funds) and state and local governments.

${ }^{5}$ Including currency and maturity composition.

${ }^{6}$ Daily (D); Weekly (W); Monthly (M); Quarterly (Q); Annually (A); Irregular (I); Not Available (NA). 
Public Information Notice (PIN) No. 08/75 FOR IMMEDIATE RELEASE June 25, 2008
International Monetary Fund $70019^{\text {th }}$ Street, NW

Washington, D. C. 20431 USA

\section{IMF Executive Board Concludes 2008 Article IV Consultation with Benin}

On June 16, 2008, the Executive Board of the International Monetary Fund (IMF) concluded the Article IV consultation with Benin. ${ }^{1}$

\section{Background}

In the last two years, Benin has experienced a pickup in growth and low inflation supported by prudent fiscal policies and external debt relief. However, progress in addressing core economic vulnerabilities has fallen short of expectations, and the external environment has become less favorable with a strengthening CFA franc adding to competitiveness concerns and surging food and fuel prices accentuating a deterioration in the terms of trade. Against this background, real GDP growth reached 4.6 percent in 2007 underpinned by activity in the port, transport and commerce sectors on the strength of enhanced Cotonou port competitiveness; and by a favorable food harvest. These factors countered the adverse impact of a regional energy crisis and lower-thanprogrammed cotton output. As a result of comfortable local food availability, average inflation decelerated to 1.3 percent in 2007, below the West African Economic and Monetary Union (WAEMU) threshold of 3 percent. This helped to moderate appreciation of the real effective exchange rate (REER).

\footnotetext{
${ }^{1}$ Under Article IV of the IMF's Articles of Agreement, the IMF holds bilateral discussions with members, usually every year. A staff team visits the country, collects economic and financial information, and discusses with officials the country's economic developments and policies. On return to headquarters, the staff prepares a report, which forms the basis for discussion by the Executive Board. At the conclusion of the discussion, the Managing Director, as Chairman of the Board, summarizes the views of Executive Directors, and this summary is transmitted to the country's authorities. This PIN summarizes the views of the Executive Board as expressed during the 6/16/2008 Executive Board discussion based on the staff report.
} 
The external current account deficit widened because of terms of trade deterioration and real currency appreciation. However, thanks to large official capital grant inflows, the balance of payments recorded a sizable surplus. Driven by strong revenue mobilization, fiscal performance exceeded expectations in several respects, although public investment lagged owing to persistent absorptive capacity limitations. At 3 percent of GDP, the surplus on the narrowly defined primary fiscal balance was 2 percentage points above target. However, higher food and fuel prices are expected to contribute to a 2.3 percent of GDP increase in the import bill in 2008 and a widening of the current account deficit.

In 2007, broad money rose by 18 percent, substantially above nominal GDP growth, driven mostly by donor-supported increases in net foreign assets. Consistent with the improved budgetary situation and related increases in Treasury deposits in the banking system, net bank credit to the government contracted, allowing a 26 percent expansion of credit to the private sector, mostly for commerce, transportation, and telecommunications activities. Because of the strong credit expansion, the authorities kept the required reserve ratio at 15 percent to insure against potential inflationary and capital flight repercussions.

Despite further delays in structural reforms in the cotton and utilities sectors, a revival of port and other service activities, together with continued, albeit moderate, recovery in cotton production, is supporting a further strengthening of growth in 2008. Real GDP growth is expected to inch up to 5.3 percent. However, continuing upward pressures on oil and food prices are likely to reverse a recent easing of pressures on domestic prices, causing average inflation to increase to the upper bound of the WAEMU target (possibly beyond in case of pronounced world oil and food price increases), despite the supply of domestic foodstuffs remaining generally adequate.

The surplus on the narrowly defined primary budget is projected to decline to 0.5 percent of GDP in 2008 reflecting, in part, revenue losses from fiscal measures to address rising oil and food prices. Nevertheless, fiscal prospects continue to benefit from expenditure and revenue measures aimed at restoring fiscal discipline and expanding the fiscal space in the post-Multilateral Debt Relief Initiative (MDRI) era. These measures are aimed at achieving enhanced monitoring of treasury operations, further improving governance in the revenue agencies, and consolidating hard-won gains in fiscal and customs administration over the last years with technical assistance from the Fund's Fiscal Affairs Department.

Benin's medium-term economic prospects seem generally favorable, although growth is likely to continue to fall short of what is required to rapidly reduce poverty. Economic activity will remain heavily dependent on performance in the port and cotton sectors, with a pickup in construction and public works supporting domestic demand as the government rebuilds the economic and social infrastructure. Cotton production and export growth are projected to remain below potential in view of slow progress in sector reform and imports of oil and capital goods would grow moderately in real terms due to capacity limitations, but also reflecting high world prices. Consistent with likely developments in the latter, the terms of trade are projected to further deteriorate. 
In the structural area, key medium-term challenges for the authorities are to (i) complete a comprehensive cotton sector reform strategy by end-2008 and ensure an early implementation of recommendations, (ii) bring to the point of sale the state-owned Telecommunications company (Benin Telecoms) in the last quarter of 2009, (iii) finalize before end-2009 restructuring of the parastatal national electricity company (SBEE) and develop a reform strategy for the company thereafter. Efforts to further enhance port competitiveness are continuing, aimed to ensure that the newly recruited external port expert and auditor become fully operational and to start operation of the port's one-stop window for customs procedures clearance in 2008. Other elements of the structural reform agenda include donor-supported initiatives to improve the efficiency of the legal and land tenure systems, and to facilitate credit assess to small and medium-sized enterprises.

A revised Poverty Reduction Strategy Paper (PRSP II) was completed in 2007. It places a renewed emphasis on private sector-led economic growth; the authorities are expected to issue a first annual progress report in the coming weeks.

\section{Executive Board Assessment}

Executive Directors commended Benin's satisfactory economic performance over the last two years, marked by low inflation and strengthening economic growth. Directors noted that Benin was the only WAEMU member country in 2007 to meet the monetary union's convergence criterion on the basic fiscal balance.

At the same time, Directors observed that growth continues to fall short of levels required to achieve significant progress in poverty alleviation, and that core economic vulnerabilities remain. In particular, rising commodity and food prices are fuelling inflationary pressures, the external current account is widening because of terms of trade deterioration and real currency appreciation, and Benin's weak absorptive capacity hampers efforts to boost growth.

Noting the slow progress of structural reform, Directors called on the authorities to invigorate the reform process - particularly in the cotton and public utility sectors-in order to reduce Benin's vulnerability to shocks, strengthen external competitiveness, improve the business environment, and further boost economic growth to accelerate progress toward the Millennium Development Goals. This will also help unlock donor financing. In this regard, Directors were encouraged by the authorities' renewed commitment to engage in a comprehensive reform agenda.

Directors noted that the fiscal measures taken to address rising food and fuel pricesnamely, reduction of tariffs on certain food and oil imports and subsidies to the electricity company-have weakened Benin's budgetary position in 2008. They called on the authorities to limit the scope and duration of these measures, and supported an early transition to well-targeted and more fiscally sustainable safety net measures. Directors encouraged the donor community to provide additional assistance to help Benin cope with the food and fuel price shock. In this regard, most Directors supported an augmentation of 
Fund financing to Benin, while some Directors expressed reservations given Benin's strong international reserve position.

Directors commended the authorities' prudent fiscal stance and the implementation of measures to improve revenue collection and control public spending. They called for further improvements in public expenditure management, and reiterated that reform of the civil service pension fund will be essential for achieving medium-term fiscal sustainability. Directors encouraged the authorities to remove the ceiling on wages as progress is made on wage management. At the same time, Directors emphasized that project design and implementation capacity needs to be strengthened to permit higher and more efficient development and social spending.

Directors welcomed the authorities' commitment to maintaining prudent borrowing policies in order to preserve external debt sustainability. However, they expressed concern that substantial borrowing has been undertaken in regional financial markets at high interest rates, only to result in an accumulation of funds in the banking system because of capacity constraints on spending.

Directors looked forward to the finalization of the comprehensive reform strategy being prepared for the cotton sector, and encouraged that the strategy be expeditiously implemented once it is completed. They called on the authorities to adhere to the new restructuring timetable for the telecommunications and electricity companies. Directors welcomed the achievements in port reform, including planned introduction of a one-stop window for customs clearance, which should help improve port management and enhance customs effectiveness. Directors also encouraged timely implementation of measures to strengthen the judicial and land tenure systems and to facilitate further access to credit for small and medium-sized enterprises.

Directors noted the weaknesses in banking sector indicators, including low capitalization, maturity mismatches, and high concentrations of credit and non-performing loans. They welcomed the authorities' endorsement of key recommendations from the recent WAEMU Financial Sector Assessment Program (FSAP) mission to improve financial sector regulation and supervision. Directors supported the recent regional agreement to strengthen the supervisory authority of the regional Banking Commission, and welcomed the regional central bank's efforts to ensure timely observance of agreed higher bank minimum capital requirements. 
Benin: Selected Economic Indicators, 2005-08

\begin{tabular}{|c|c|c|c|c|}
\hline & 2005 & 2006 & 2007 & 2008 \\
\hline & \multicolumn{4}{|c|}{ (Annual changes in percent) } \\
\hline \multicolumn{5}{|l|}{ Income and prices } \\
\hline Real GDP & 2.9 & 3.8 & 4.6 & 5.3 \\
\hline Consumer prices (average) & 5.4 & 3.8 & 1.3 & 2.9 \\
\hline Real effective exchange rate & 2.2 & 1.1 & 1.2 & $\ldots$ \\
\hline \multirow[t]{2}{*}{ Terms of trade } & -15.9 & -7.8 & -0.2 & -5.0 \\
\hline & \multicolumn{4}{|c|}{ (Annual change in percent of beginning-of-period broad money) } \\
\hline \multicolumn{5}{|l|}{ Money and credit } \\
\hline Net foreign assets & 8.8 & 20.6 & 18.3 & 2.1 \\
\hline Broad money & 21.8 & 16.5 & 18.0 & 8.3 \\
\hline Credit to the nongovernment sector & 20.2 & 4.6 & 13.0 & 6.7 \\
\hline Net credit to central government & 3.2 & -7.3 & -16.0 & -0.5 \\
\hline & \multicolumn{4}{|c|}{ (In percent of GDP, unless otherwise indicated) } \\
\hline \multicolumn{5}{|l|}{ Investment and saving } \\
\hline Gross domestic investment & 19.6 & 18.1 & 21.4 & 22.1 \\
\hline Gross national saving & 12.9 & 12.4 & 15.2 & 15.2 \\
\hline \multicolumn{5}{|l|}{ External sector } \\
\hline Current account balance & -7.1 & -6.4 & -6.9 & -7.5 \\
\hline Overall balance of payments & 3.0 & 4.7 & 3.2 & 0.7 \\
\hline $\begin{array}{l}\text { NPV of debt to export of goods and } \\
\text { nonfactor services }\end{array}$ & 81.6 & 88.5 & 87.2 & 84.6 \\
\hline \multicolumn{5}{|l|}{ Central government finance } \\
\hline Central government revenue & 16.5 & 16.8 & 20.6 & 18.4 \\
\hline Total expenditure and net lending & 21.1 & 19.5 & 22.0 & 22.8 \\
\hline Primary fiscal balance & -4.3 & -2.3 & -1.2 & -4.0 \\
\hline Overall fiscal balance & -3.6 & -2.7 & -1.4 & -4.4 \\
\hline
\end{tabular}

Sources: Beninese authorities; and IMF staff calculation and estimates 
Press Release No. 08/139

International Monetary Fund

FOR IMMEDIATE RELEASE

Washington, D.C. 20431 USA

June 16, 2008

\section{IMF Executive Board Completes Fourth Review Under the PRGF Arrangement with Benin, Increases Financial Assistance by 150 Percent to Mitigate Food and Fuels Price Impact, and Approves US\$16.4 Million Disbursement}

The Executive Board of the International Monetary Fund (IMF) today completed the fourth review of Benin's economic performance under the Poverty Reduction and Growth Facility (PRGF) arrangement and increased access to financial assistance under the arrangement by 150 percent to help the country deal with rising food and oil prices. The Board agreed to augment the SDR 6.19 million (about US\$10 million) arrangement with SDR 9.29 million (about US\$15 million). The completion of the review enables the disbursement of an amount equivalent to SDR 10.17 million (about US\$16.4 million), including the augmented amount.

The three-year PRGF arrangement was approved on August 5, 2005 (see Press Release

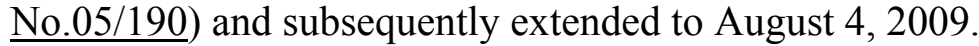

In completing the review, Mr. Murilo Portugal, Deputy Managing Director and Acting Chair, stated:

"Supported by prudent fiscal policies and external debt relief, economic growth in Benin has picked up and inflation remains low. However, an increasingly less favorable external environment is likely to complicate the task of raising growth further and reducing poverty faster. Rising food and fuel prices have further worsened Benin's terms of trade, pushed up inflation sharply, and adversely affected vulnerable social groups.

"The authorities are cognizant of the need to consolidate Benin's recent gains in macroeconomic stability, as underscored in the country's Growth Strategy for Poverty Reduction (GSPR). Nonetheless, in this difficult environment the authorities are allowing a temporary increase in the fiscal deficit in 2008, through tax cuts and subsidies, to smooth adjustment to higher food and fuel prices. These measures will be replaced by well-targeted safety net measures in due course. Over the medium term, full pass-through of food and fuel price increases to consumers will be key to helping the economy adjust and to foster a positive agricultural supply response. The Fund is increasing the resources it makes available to help the authorities to smooth this adjustment.

"The underlying fiscal performance continues to improve with the implementation of measures to increase revenue and contain spending. Especially noteworthy have been the 
efforts to improve governance in the revenue agencies and to strengthen tax and customs administration. The government's infrastructure rehabilitation program is rebounding, although capital outlays remain constrained by absorptive capacity limitations. To address these limitations, the authorities are strengthening the government's expertise in project design and implementation. Preservation of fiscal and debt sustainability will require continued prudent debt management, especially reliance on highly concessional external financing. These fiscal reform efforts will create increased fiscal space for poverty reduction and growth-supporting expenditures.

"The structural reform program is moving slowly. The authorities are encouraged to accelerate implementation of reforms in key sectors in order to reduce core economic vulnerabilities. A major element of the 2008 structural reform agenda is the completion of a comprehensive reform strategy for the cotton sector. Also critical are actions to advance with the restructuring of the state-owned telecommunications and electricity companies. Reforms in the judicial and land tenure systems will continue to support efforts to facilitate access to credit for small- and medium-sized enterprises," Mr. Portugal said.

The PRGF is the IMF's concessional facility for low-income countries. It is intended that PRGF-supported programs are based on country-owned poverty reduction strategies adopted in a participatory process involving civil society and development partners and articulated in a Poverty Reduction Strategy Paper (PRSP). This is intended to ensure that PRGF-supported programs are consistent with a comprehensive framework for macroeconomic, structural, and social policies to foster growth and reduce poverty. PRGF loans carry an annual interest rate of 0.5 percent and are repayable over 10 years with a $5 \frac{1}{2}$-year grace period on principal payments. 


\section{Statement by Laurean W. Rutayisire, Executive Director for Benin June 12, 2008}

1. On behalf of my Benin authorities, I would like to thank the Executive Board, Management and Staff for their continued support to Benin's efforts towards sustained reforms and sound macroeconomic policies. I would also like to thank staff for the fruitful discussions held during their recent visit to Cotonou. The reports tabled for the Board's discussion represent a candid assessment of the Beninese economy, and my authorities are thankful for constructive policy advice therein.

\section{Recent Developments}

2. Benin's economic performances under the PRGF-supported program continues to be broadly satisfactory, as reflected by the observance of all quantitative benchmarks for endSeptember and performance criteria for end-December 2007. With real GDP growth rate at 4.6 percent in 2007 and projected at 5.3 percent in 2008, the Beninese economy is firmly recovering from its downward trend of 2000-2005, thanks to the steady resumption of cotton production, good performance in non-cotton agriculture, and the strong activities in the port as well as related transport and commerce sectors.

3. The fiscal consolidation engaged by the authorities since 2006 continues to yield positive results. Following a sustained implementation of reform measures to improve both governance and efficiency in the tax and customs administration, revenue collection has increased to 20.6 percent in 2007, outpacing the program target of 17.2 percent. On expenditure side, the authorities continued to tighten control over spending in line with the country's absorptive capacity and the needs to ensure quality. The resulting surplus on the narrowly defined primary fiscal balance of 3 percent of GDP in 2007, compared to 1 percent targeted, enabled Benin to meet the WAEMU convergence criterion on the non-negative narrowly defined fiscal balance.

4. The implementation of fiscal structural reforms also continued to move forward, despite at slower path than wished by the authorities due partly to difficulties that were initially unforeseen. Two structural benchmarks for the period under review - namely, the introduction of Single Taxpayer Identification Number (TIN) system and a study of the efficiency of customs - were completed before end-2007. In addition, appropriate steps have been taken to ensure successful completion before the year end of the two non-observed structural benchmarks, namely the audit of PFM information systems and the design of a strategy for the reform of the civil service pension fund.

5. Owing to prudent monetary policy, as well as to good harvest, average inflation eased at 1.3 percent in 2007, compared to 3.8 percent in 2006 . However, the recent surge in food and fuel prices on the international market and its consequent inflationary pressures pose a threat to the macroeconomic stability already achieved and complicate the authorities' structural reform implementation agenda. 
6. My authorities attempted to mitigate the impacts of world food price increases, particularly on vulnerable groups, by temporarily eliminating customs tariffs and reducing customs fees on highly consumed staple food items as well as through subsidies to the energy utility company. While the measures were initially designed to end by mid-March 2008, the persistent international food crisis warranted their continuation whilst government is designing support mechanisms that better target the poor and help avoid distortions in the domestic supply of the affected products. In addition, government is searching for long-term solutions to the crisis, including through regional concerted efforts toward the development of the agriculture sector. Government have also mobilized financial resources to cover the revenue loss from the tax cuts and subsidies, but additional resources are still needed, including from the Fund to help cover the resulting balance of payments financing gaps. My authorities would much appreciate the approval of the requested support.

\section{Policy and Structural Reforms Agenda for 2008 and beyond}

7. Over the medium-term, my authorities intend to further push ahead their structural reform agenda, in order to resolve the challenging obstacles to a strong and sustained economic growth, to competitiveness and effective poverty reduction. Importantly, Benin authorities will continue to strengthen public investment, particularly in social, agriculture and infrastructure sectors, and improve the business climate. In line with these reforms, economic growth is projected to reach 5.3 percent in 2008 and average 5.5 percent annually through 2011.

8. The authorities intend to achieve the above overall objective through the maintenance of a prudent fiscal policy over the medium term in line with their PRGF program, which aims principally at preserving the macroeconomic stability achieved so far. They will strive to meet the WAEMU fiscal convergence criteria and keep demand-induced inflationary pressures in check. In 2008, they target a primary budget surplus of 0.5 percent, which in turn would allow to contain the overall fiscal deficit to equivalent of 4.4 percent of GDP and the level of debt at sustainable path, whilst effectively responding to expenditure needs particularly in the social, productive and infrastructure sectors. To this end, my authorities aim to increase revenue collections to 18.4 percent of GDP by capitalizing on the recently introduced measures to broaden tax base as well as to further improve governance in the tax and customs administrations.

9. As a step in pursuing further their fiscal consolidation, the Beninese authorities have requested Fund's assistance to help review the country's tax structure. The findings of the review would allow the authorities to harmonize their tax rates with regional peers, to find ways of further enhancing domestic tax performance in light of the expected revenues losses from the signing of the economic partnership agreements (EPA) with the EU, as well as streamlining the effectiveness of the tax regime in promoting the development of domestic private sector. The technical assistance mission in expected in the course of June 2008.

10. On expenditure side, an increase of 12.2 percent is projected to help cater for the infrastructure rehabilitation program that started in 2007, the recent increase in the salaries of public sector teachers as well as the new recruitment of public servants to reinforce the 
capacity of key sectors. At the same time however, a tightened control over current expenditure will sustain, particularly on goods and services and wage bill. To the later end, the authorities have reaffirmed their preference to keep the wage ceiling as program conditionality, along with improvements in payroll systems and progress in the reform of the civil service pension fund. My authorities will step up efforts to address problems in public procurement and projects' management systems. They will also build capacity to conduct feasibility studies, select and identify sources of financing for key infrastructure projects, and monitor their implementation. In this context, bi-monthly project execution reports will be discussed by the Council of Ministers and posted on the President's Office website.

11. My Benin authorities will continue to adhere to the prudent monetary policy conducted by the regional central bank BCEAO, which aims at preserving price stability. The Central bank targets an increase in the broad money at a rate of 8.3 percent equivalent to that of the nominal GDP in 2008 and the authorities will continue to restrain the net claims of the banking system on government following expected improvement in the public finances. As in 2007, this will allow for increase in credit to the private sector.

12. Steps continue to be taken to addressing the current vulnerabilities in the banking system. Government is carefully monitoring the implementation of the BCEAO decision to adjust the minimum capital from CFAF 1 billion to 10 billion over three years. Further, it is working with parliament to speed up the ratification of the regional agreement enhancing the supervisory powers of the WAEMU Banking Commission. With support from BCEAO national office, the technical ministry in charge of microfinance is increasing its supervision capacity, while oversight of large microfinance institutions falls under the BCEAO national office's responsibility. An evaluation of financial services demand has been completed under MCA-Benin's support. With all these findings as well as those from the recent regional FSA, the Beninese authorities intend to design a comprehensive strategy for development of the financial sector, which will help identify additional measures not only to reinforce the banking sector compliance but also to improve access to credit, especially by small - and medium-sized enterprises. The development of the financial sector, together with efforts supported by MCA-Benin to improve land tenure and the legal system, will help in creating an enabling environment for private sector businesses and diversification of the economy.

13. The implementation of other structural reforms will also continue to move forward, despite the challenging socio-political environment and insufficient capacity that constrain the political will of the authorities to accelerate them. With local elections recently completed, a new impetus to the reform program is expected, including pushing ahead the administrative and financial decentralization agenda. Furthermore, the authorities are determined to continue enhancing dialogue on the economic benefits of the structural reform agenda by further involving participation of stakeholder groups and requesting technical support from donors.

14. Following the recent disappointing attempt to disengage the state from SONAPRA, principally due to limited private sector interest, the government is preparing a comprehensive strategy for the reform of the cotton sector. The new strategy will go beyond the solely state disengagement from the ginning activities, and tackle all aspects of 
the production and marketing chains. As an initial step, the government recently decided not to interfere with the awarding of contracts for importation and distribution of fertilizers and other inputs. In addition, a Strategic Policy Paper, which gives the main orientations of the reform, was approved by the Council of Ministers on May 19, 2008. The next step is the conduct of participatory consultations involving key stakeholder groups with a view to securing broad-based ownership of the reform. The process for the design of the strategy is expected to be completed by end-December 2008, while the implementation of the agreed measures is initially set to extend over a 2-3 year period.

15. Regarding the privatization of Bénin Telecoms, the implementation of its restructuring plan is under way, as approved by government and endorsed by main creditors. Furthermore, the policy measures taken by the authorities in 2007 have helped the GSM mobile phone telecommunication companies to fully resume activities and the interim regulatory authority - le Conseil Transitoire de Régulation des Postes et Télécommunications - has started to effectively perform its oversight prerogatives. As for the Société Béninoise d'Electricité et Energie (SBEE), the implementation of the restructuring is to last 2 years effective from January 2008 through December 2009, after which the government will make assessment to determine the nature of privatization.

16. Implementation of reforms to enhance the efficiency and competitiveness of the Port of Cotonou is advancing well. A "Port Expert", who will help in the day-to-day management of the port, is to be operational by end of this month. Further improvement in the port competitiveness would derive from the effective implementation of the Virtual One-Stop Shop and the Consolidated Electronic Billing System (Bordereau de Facturation Unique), which are expected by end-September 2008.

17. My Beninese authorities are thankful to the international community for its continued support, and for having chosen Benin among the 10 countries for which increased international support is being planned as part of the UN push to fast-track progress toward the MDGs. The Government believes that its reform agenda as embedded in the Growth Strategy for Poverty Reduction Paper (2007-2009) offers an appropriate framework for channeling the envisaged scaled-up aid. It looks forward to the completion of the assessment of the macroeconomic implication of the anticipated higher external assistance, expected later in 2008, as well as to continue working with the donors' community on building the country's capacity for policy design and implementation.

\section{Conclusion}

With the above commendable achievements, my authorities have once again demonstrated their commitment to - and ownership of - policies reforms laid out under the ongoing PRGFsupported program. Though challenges are still daunting, and some of the reforms will take time to fully yield sustained results, my authorities are committed to pursue their endeavors, accelerate the pace of the reforms to transform the Beninese economy. In view of the achievements during the period under review and the continuing commitment of the authorities to push ahead their reform agenda, I will appreciate the Board's support for the 
completion of the fourth review, and the approval for the requested augmentation of access under PRGF, as well as the completion of the 2008 Article IV consultations. 